\title{
Effect of permafrost thawing on organic carbon and trace element colloidal speciation in the thermokarst lakes of western Siberia
}

\author{
O. S. Pokrovsky ${ }^{1}$, L. S. Shirokova ${ }^{2}$, S. N. Kirpotin $^{3}$, S. Audry ${ }^{1}$, J. Viers ${ }^{1}$, and B. Dupré ${ }^{1}$ \\ ${ }^{1}$ LMTG-GET, UMR 5563 CNRS (INSU), Université de Toulouse, Avenue Edouard Belin, 31400, Toulouse, France \\ ${ }^{2}$ Laboratory of Aquatic Ecosystems, Institute of Ecological Problems of the North, Ural Branch Russian Academy of Science, \\ Arkhangelsk, 163000, Russia \\ ${ }^{3}$ Tomsk State University, 36, Lenina Prospekt, Tomsk, 634050, Russia
}

Received: 19 October 2010 - Published in Biogeosciences Discuss.: 2 November 2010

Revised: 3 February 2011 - Accepted: 18 February 2011 - Published: 4 March 2011

\begin{abstract}
To examine the mechanisms of carbon mobilization and biodegradation during permafrost thawing and to establish a link between organic carbon (OC) and other chemical and microbiological parameters in forming thermokarst (thaw) lakes, we studied the biogeochemistry of OC and trace elements (TEs) in a chronosequence of small lakes that are being formed due to permafrost thawing in the northern part of western Siberia. Twenty lakes and small ponds of various sizes and ages were sampled for dissolved and colloidal organic carbon, metals and culturable heterotrophic bacterial cell number. We observed a sequence of ecosystems from peat thawing and palsa degradation due to permafrost subsidence in small ponds to large, $\mathrm{km}$-size lakes that are subject to drainage to, finally, the khasyrey (drained lake) formation. There is a systematic evolution of both total dissolved and colloidal concentration of OC and TEs in the lake water along with the chronosequence of lake development that may be directly linked to the microbial mineralization of dissolved organic matter and the liberation of the inorganic components ( $\mathrm{Fe}, \mathrm{Al}$, and TEs) from the organo-mineral colloids.

In this chronosequence of lake development, we observed an apparent decrease in the relative proportion of low molecular weight $<1 \mathrm{kDa}(1 \mathrm{kDa} \sim 1 \mathrm{~nm})$ OC concentration along with a decrease in the concentration of total dissolved $(<0.45 \mu \mathrm{m})$ OC. This decrease was accompanied by an increase in the small size organic ligands (probably autochthonous exometabolites produced by the phytoplankton) and a simultaneous decrease in the proportion of large-size organic (humic) complexes of allochthonous (soil) origin.
\end{abstract}

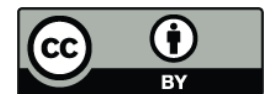

Correspondence to: O. S. Pokrovsky (oleg@get.obs-mip.fr)
This evolution may be due to the activity of heterotrophic bacterioplankton that use allochthonous organic matter and dissolved nutrients originating from peat lixiviation. Most insoluble TEs demonstrate a systematic decrease in concentration during filtration $(5 \mu \mathrm{m}, 0.45 \mu \mathrm{m})$ exhibiting a similar pattern among different samples. At the same time, there is an increase in the relative proportion of large size particles over the $<1 \mathrm{kDa}$ fraction for most insoluble elements along the chronosequence of lake evolution. TEs are likely to be bound to colloidal OC and coprecipitate with the mineral (Fe, Al) part of the colloids. Upon progressive consumption of dissolved OC by the heterotrophic bacteria, there is liberation of $\mathrm{Fe}, \mathrm{Al}$, and insoluble TEs in the water column that may be subjected to coagulation in the form of particles or large-size mineral colloids.

\section{Introduction}

Thawing permafrost and the resulting microbial decomposition of previously frozen organic carbon are among the most significant processes that provide positive feedback to a warming climate (Schuur et al., 2008). Ongoing processes of permafrost thawing in western Siberia are likely to increase the surface of water bodies via the formation of the alleged thermokarst lakes, mobilizing the organic carbon (OC) from the soil pool to the rivers and, eventually into the ocean, thus modifying the fluxes of methane $\left(\mathrm{CH}_{4}\right)$ and $\mathrm{CO}_{2}$ in the atmosphere (Smith et al., 2005; Walter et al., 2006, 2007). The overall potential of carbon loss from yedoma (permafrost) soils under a scenario of continued warming is estimated at $1 \mathrm{GtC} \mathrm{yr}^{-1}$ or $\sim 40 \mathrm{GtC}$ in the next four decades (Dutta et al., 2006), while $100 \mathrm{GtC}$ could be released from thawing

Published by Copernicus Publications on behalf of the European Geosciences Union. 
permafrost by 2100 (Gruber et al., 2004). A significant part of this carbon flux will be mediated by active hydrological systems because microbial decomposition of organic matter $(\mathrm{OM})$ is strongly limited by water abundance. In addition, thermokarst (thaw) lakes that are formed due to ground surface subsidence caused by the thawing of ice-rich permafrost may cause a significant and abrupt acceleration of the carbon mobilization process, which may be more important than the one occurring in the soils. This acceleration is due to the large surface and volume of water available for microbial processing of allochthonous OM and larger periods of liquid (unfrozen) water persistence in the lakes as compared to that in the soils. Moreover, it has been known for a long time that the boreal lakes and rivers yield a net annual $\mathrm{CO}_{2}$ evasion into the atmosphere (referred to as the net heterotrophy) and that between $30 \%$ and $80 \%$ of the total OC that enters the freshwater ecosystems is lost in lakes via the mineralization and subsequent $\mathrm{CO}_{2}$ emission into the atmosphere (Cole et al., 1994, 2007; Hope et al., 1996; Kelly et al., 2001; Sobek et al., 2003; Teodoru et al., 2009; Tranvik et al., 2009). Up until now, however, all measurements of this flux used direct (chambers) or indirect (isotopes, $p \mathrm{CO}_{2}$ values) techniques to assess the concentrations of $\mathrm{CO}_{2}$ in the boundary air or the liquid phase (e.g., Kling et al., 1991), whereas the chemical and microbiological mechanisms of this process in the water column remained poorly understood. By drawing an analogy with the non-permafrost affected environments (Tranvik, 1988; Kritzberg et al., 2004), the net heterotrophic status of thermokarst lakes may be attributed to the bacterial utilization of allochthonous OC originating from peat erosion.

Small thermokarst lakes located between the $\mathrm{Ob}$ and Yenissey Rivers in the northern part of the western Siberian Plain present a unique opportunity to test this hypothesis by studying lake formation and drainage within the chronosequence of ecosystem development (e.g., Kirpotin et al., 2007, 2008a, b, 2009; Shirokova et al., 2009). There are only a few detailed studies of thaw lakes located in the subarctic zone. Zimov et al. (1997) investigated methane concentration and fluxes in permafrost lakes located on the Kolyma lowland (yedoma complex), but the information on OC, bacterioplankton, and dissolved major and trace elements (TEs) was not collected. The thermokarst depressions (alases) of central Yakutia have been extensively studied over the past decade (Desyatkin, 2008; Desyatkin et al., 2009); however, specific lithological and glacial contexts of this region do not allow a direct comparison with the western Siberian Palsa. The thaw lakes of northern Canada and Alaska have been investigated since the early 1970s (Prentki et al., 1980), but only recently, systematic characteristics of lakes hydrochemistry and microbiology have become available (Pienitz et al., 2008; Breton et al., 2009). A thorough study by Laurion et al. (2010) assessed the main hydrochemical and hydrobiological characteristics of $\sim 50$ lakes and ponds located in the forest-tundra and tundra zones of Canada. Most shallow $(2-5 \mathrm{~m})$ lakes were strongly stratified during summer with the average dissolved organic carbon (DOC) concentration of 5 to $12 \mathrm{mg} \mathrm{L}^{-1}$ and $\mathrm{pH}$ values ranging from 6.2 to 9.6 . Additionally, most lakes exhibited net heterotrophy (supersaturation with respect to atmospheric $\mathrm{CO}_{2}$ ). Together with reliable data on the hydrochemistry of lakes located in south Canada and northern Europe, the results of that study potentially allow for the extrapolation of the existing information onto the whole boreal zone. However, the vast area of western Siberia containing the largest peat resources in the world, dominated by discontinuous permafrost and thus being potentially the most vulnerable part of the boreal permafrostbearing zone, remains poorly understood. In contrast to several studies on the western Siberian rivers (Frey and Smith, 2005; Frey et al., 2007; Frey and McClelland, 2009; Gordeev et al., 2004), lakes and Arctic ponds of eastern and central Siberia (Semiletov et al., 1996; Zimov et al., 1997; Blodau et al., 2008), the lakes of western Siberia remained virtually unexplored, both from the viewpoint of OC and bacterioplankton concentration as well as the trace element (TE) speciation and colloidal status. In consideration of the very high proportion of newly formed lakes in western Siberia (up to $48 \%$ of the surface area) (Zimov et al., 1997; Hinkel et al., 2003; Riordan et al., 2006) and as high as 60-80\% in the Pur Taz and Nadum river basins (Zakharova et al., 2009), there is little doubt that the western Siberian thermokarst lakes are likely to act as an important source of $\mathrm{CO}_{2}$ in the atmosphere.

Based on this rationale, our objective was to test the hypothesis that thermokarst lakes are efficient mediators of carbon flux from the soil to the atmosphere via bacterial decomposition of dissolved OM. In consideration of the extremely high concentration of DOC reported in the lakes of western Siberia that developed on the peat deposits, the largest part of the total dissolved carbon along with trace and other major elements is likely to be colloidal. To improve our understanding of carbon and related element biogeochemistry in shallow thermokarst lakes, we aimed to address the following specific issues: (1) assess the variations in TE and OC concentrations along with the chronosequence of lake development; and (2) characterize the colloidal status of TEs and distinguish between the relative proportion of organic and organo-mineral colloids.

\section{Methods}

\subsection{Study site description}

The study site is located in the northern part of western Siberia $\left(65.5-66^{\circ} \mathrm{N}\right)$ between the rivers Nadym and Pur, within the tundra and forest-tundra landscapes developed on continuous permafrost $\leq 100 \mathrm{~m}$ depth over the Neocene sand and clay deposits covered by a 1-2 m thick peat layer (Fig. 1). Although the area was subjected to multiple glaciations during the Pleistocene age (Arkhipov et al., 1986), all studied lakes were of permafrost melting origin (soil subsidence) that 

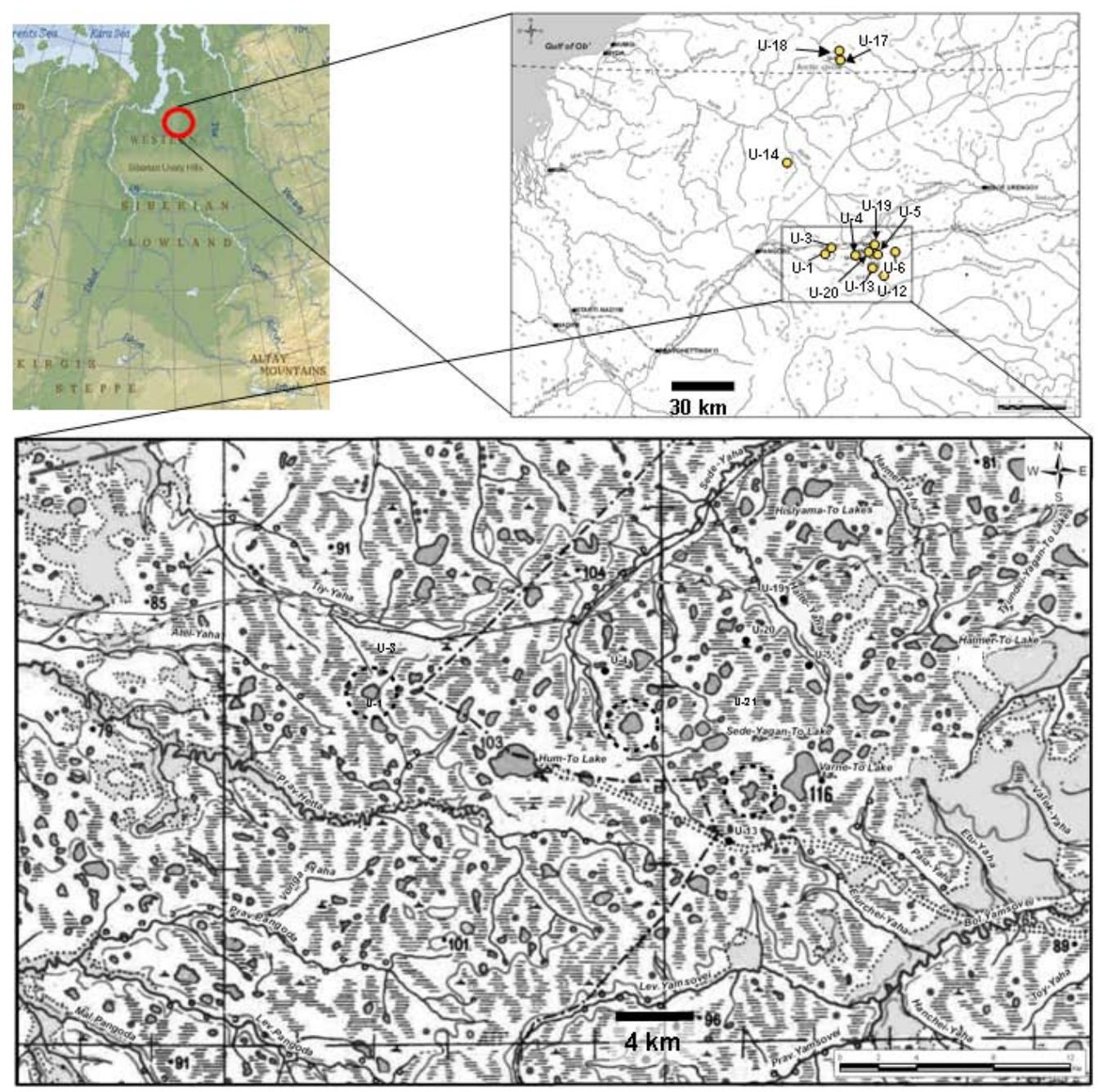

Fig. 1. Schematic map of the studied area.

occurred via cyclical events of peat palsa development as illustrated in photos 1 to 5 of the Supplement (ESM-1). This chronosequence of ecosystem evolution from peat thawing and palsa degradation due to permafrost subsidence in small ponds to large, $\mathrm{km}$-size lakes subject to drainage to, finally, the khasyrey (drained lake) formation revealed in recent studies based on ground and remote sensing observations (Kirpotin et al., 2007, 2008a, b, 2009; Shirokova et al., 2009) is illustrated in Fig. 2 and briefly discussed below. First, a crack appears in the lichen cover of the surface of the frozen mound; this decreases the albedo of the surface and leads to further peat degradation. The palsa depression is then filled by the water from the thawing. The size of the depression increases forming a shallow round lake characterized by intensive peat abrasion at the border. At this stage of the system development, the water is acidic ( $\mathrm{pH}$ value ranging from 3 to 4) and rich in DOC (20 to $80 \mathrm{mg} \mathrm{L}^{-1}$ ). Eventually, the lake border is stabilized, and water becomes less acidic and less organic. At this mature stage of development, the lake has a
$\mathrm{pH}$ value in the range of 5 to 6 and a DOC concentration of approximately $10-15 \mathrm{mg} \mathrm{L}^{-1}$. The final stage of the ecosystem development consists of lake drainage into another larger water system or into the hydrological network, and a subsequent formation of the lake's dry bottom (khasyrey) with a small water body remaining in the center of the drained lake. During this period, the lake becomes productive and there is a presence of aquatic plants, phytoplankton and zooplankton. In this study, we have only qualitative data on the presence of phytoplankton and zooplankton in mature lakes and khasyreys. The old khasyrey initiates a new stage of frozen mound degradation enabling the formation of the new pond. The lakes and ponds are typically glaciated from October to May. Their shallow depths ( 0.5 to $1.5 \mathrm{~m}$ ), location within the tundra and strong winds favor thick ice coverage in winter and intensive wave mixing in the summer. 


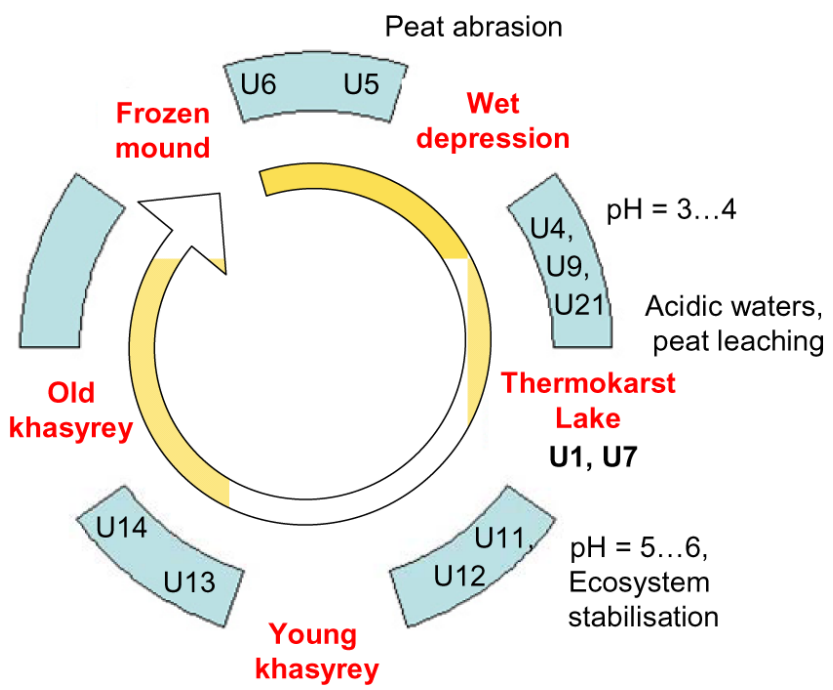

Fig. 2. Scheme of cyclic succession of thermokarst lakes and khasyrey development from flat and mound bogs. The numbers from U1 to U21 correspond to some of the water samples collected in this study at various stages of lake development (Table 1 and Fig. 1).

\subsection{Sampling and analyses}

The list of the sampled objects together with the main hydrochemical characteristics is presented in Table 1. The sampling, filtration, and dialysis as well as the chemical analyses techniques are very similar to those used in our previous studies (Pokrovsky and Schott, 2002; Pokrovsky et al., 2006, 2010; Vasyukova et al., 2010). Ultraclean sampling procedure was used throughout all manipulations in the field (Shirokova et al., 2010). Sampling of $\sim 20$ ponds, lakes and streams was performed in August 2008, and for several large lakes, sampling was performed in March 2010. The water samples were taken from a PVC boat from the central part of the lake and immediately filtered through sterile, single-use Minisart ${ }^{\circledR}$ filter units (Sartorius, acetate cellulose filter) with pore sizes of 5 or $0.45 \mu \mathrm{m}$. The first $100 \mathrm{ml}$ of the filtrate was systematically discarded. Because the lakes were completely frozen to the bottom in March, filtration through $0.45 \mu \mathrm{m}$ pore sizes only was performed for these samples after melting the entire ice block sampled approximately $0.5 \mathrm{~m}$ above the bottom. Dissolved oxygen and $\mathrm{pH}$ were measured on-site with an uncertainty of $5 \%$ and 0.02 units, respectively.

In August 2008, in-situ dialysis experiments were performed using $20-50 \mathrm{ml}$ precleaned dialysis bags placed directly in the lake. The duration of this dialysis procedure was between 72 and $96 \mathrm{~h}$. The exposure time was selected based on the kinetic experiments of dialysis equilibrium attainment for DOC, Si and trace metals as illustrated in Fig. 3. For the dialysis experiments, EDTA-cleaned trace-metal pure SpectraPor $7{ }^{\circledR}$ dialysis membranes made of regenerated cellulose having pore sizes of $10,3.5$ and $1 \mathrm{kDa}$ were thoroughly

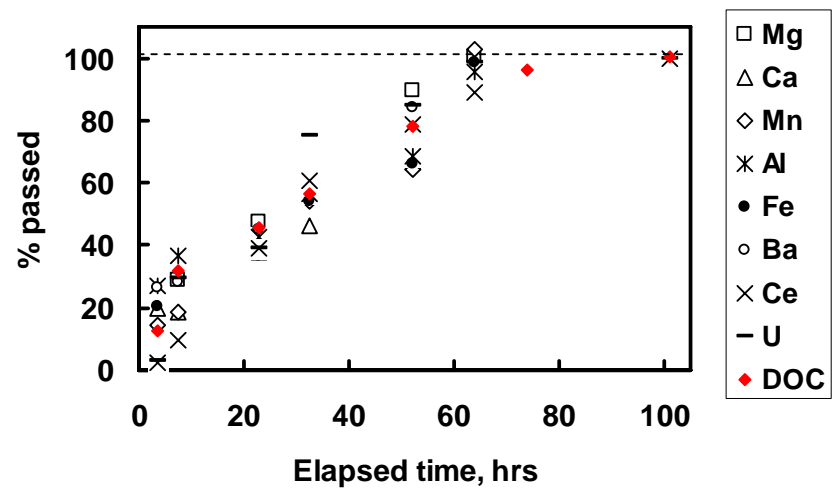

Fig. 3. Percentage of element passed through $1 \mathrm{kDa}$ dialysis membrane as a function of time. Element concentration in the $<1 \mathrm{kDa}$ after $100 \mathrm{~h}$ exposure is taken as $100 \%$.

washed in $0.1 \mathrm{M}$ double-distilled $\mathrm{HNO}_{3}$ and ultrapure water, then filled with ultrapure MilliQ deionized water and finally placed in the lake water. The efficiency of the dialysis procedure was evaluated by comparing the concentration of the major anion or neutral species (e.g., $\mathrm{Cl}^{-}, \mathrm{H}_{4} \mathrm{SiO}_{4}^{\circ}$ ) not associated with the colloids between the dialysis bag and the external solution. These concentrations were always identical within $\pm 20 \%$, suggesting an equilibrium distribution of dissolved components. To assess the mass balance during the dialysis procedure, concentrations of major and trace elements and OC were measured in the external solution and internal compartments, and compared with $<0.45 \mu \mathrm{m}$ filtrates. In all the cases, better than $95 \%$ recovery for the major elements, namely $\mathrm{OC}, \mathrm{Al}$, and $\mathrm{Fe}$, and $90 \%$ recovery for the selected TEs (Ti, Sr, Y, Ba and Zr) was achieved, indicating that the adsorption of colloids and associated TEs onto and inside the thin Spectra Por 7 membrane was negligible.

Concentrations of DOC, $\mathrm{Cl}, \mathrm{SO}_{4}$, Alk, cations and TEs were measured using the methods routinely used in our laboratory for analysis of boreal organic-rich water samples (Vasyukova et al., 2010; Pokrovsky et al., 2010). Filtered and dialyzed samples were stored at $4-5^{\circ} \mathrm{C}$ in the dark before the analysis. The storage temperature was reduced to decrease the coagulation and bacterial production in the experimental samples (Chen and Buffle, 1996; Wilkinson et al., 1997).

For culturable heterotrophic bacteria enumeration, samples were collected in sterile $250-\mathrm{mL}$ flasks and stored at $6-8{ }^{\circ} \mathrm{C}$ in the dark for less than $3 \mathrm{~h}$ before culturing. The inoculation for culturing was performed in a prepared laboratory space sterilized by a UV lamp near an open flame. Blanks were always run for the sterile control. Two duplicates of different volumes of lake water (normally $0.5,1$ and $5 \mathrm{~mL}$ ) were inoculated on Bacto agar nutrient media for the enumeration of eutrophic bacteria. The number of colonyforming units (CFU) was evaluated by the optical counting of colonies on the agar plate after 5 days of incubation at 
Table 1. Physical and hydrochemical characteristics of studied ponds and lakes.

\begin{tabular}{|c|c|c|c|c|c|c|c|c|c|c|c|c|c|c|c|}
\hline Sample & Description & $\begin{array}{l}\text { Sampling } \\
\text { depth, } \mathrm{m}\end{array}$ & $\begin{array}{l}\text { Water surface } \\
\text { area }\end{array}$ & $\mathrm{N}$ & $\mathrm{E}$ & $\begin{array}{l}T, \\
{ }^{\circ} \mathrm{C}\end{array}$ & $\begin{array}{c}\mathrm{O}_{2} \\
\mathrm{mg} \mathrm{L}^{-1}\end{array}$ & $\mathrm{pH}$ & $\begin{array}{c}\text { Cond., } \\
\mu \mathrm{S}\end{array}$ & $\begin{array}{l}\text { Alk, } \\
\text { M }\end{array}$ & $\begin{array}{l}\mathrm{Cl}, \\
\mathrm{ppm}\end{array}$ & $\begin{array}{l}\mathrm{SO}_{4} \\
\mathrm{ppm}\end{array}$ & $\begin{array}{l}\text { DOC, } \\
\text { ppm }\end{array}$ & $\begin{array}{c}\text { A } 280 \\
n m\end{array}$ & $\begin{array}{l}\text { Bacteries } \\
\text { CFU } / \mathrm{mL}\end{array}$ \\
\hline U-1 & $\begin{array}{l}\text { Lake Shirokoe } \\
\text { surface }\end{array}$ & 0.5 & $0.6 \mathrm{~km}^{2}$ & $65^{\circ} 49^{\prime} 56.90^{\prime \prime}$ & $75^{\circ} 10^{\prime} 11.17^{\prime \prime}$ & 11.9 & 9.5 & 3.70 & 47.7 & $<$ d.1. & 0.237 & 2.973 & 10.6 & 0.22 & 2350 \\
\hline $\mathrm{U}-2$ & $\begin{array}{l}\text { Lake Shirokoe } \\
\text { bottom }\end{array}$ & 1.25 & $0.6 \mathrm{~km}^{2}$ & $65^{\circ} 49^{\prime} 56.90^{\prime \prime}$ & $75^{\circ} 10^{\prime} 11.17^{\prime \prime}$ & 11.6 & 9.2 & 3.26 & 53.1 & $<$ d.1. & 0.489 & 3.066 & 10.7 & 0.25 & 2410 \\
\hline U-3 & $\begin{array}{l}\text { Brook from } \\
\text { thawing mound }\end{array}$ & surface & N.D. & $65^{\circ} 50^{\prime} 59.5^{\prime \prime}$ & $75^{\circ} 10^{\prime} 51.6^{\prime \prime}$ & 12.6 & 7.9 & 4.13 & 9.3 & $<$ d.1. & 0.081 & 0.376 & 14.0 & 0.42 & 348 \\
\hline $\mathrm{U}-4$ & $\begin{array}{l}\text { Actively growing } \\
\text { lake }\end{array}$ & surface & $300 \mathrm{~m}^{2}$ & $65^{\circ} 50^{\prime} 20^{\prime \prime}$ & $75^{\circ} 11^{\prime} 13^{\prime \prime}$ & 12.9 & 9.9 & 3.26 & 20.3 & $<$ d.1. & 0.135 & 0.274 & 29.8 & 0.71 & 88 \\
\hline U-5 & Small pond & surface & $3 \mathrm{~m}^{2}$ & $65^{\circ} 50^{\prime} 26^{\prime \prime}$ & $75^{\circ} 11^{\prime} 25^{\prime \prime}$ & 13.5 & 2.3 & 3.67 & 27.9 & $<$ d.1. & 0.260 & 0.114 & 75.9 & 1.66 & 2760 \\
\hline U-6 & Peat abrasion & surface & $2 \mathrm{~m}^{2}$ & $65^{\circ} 50^{\prime} 35^{\prime \prime}$ & $75^{\circ} 11^{\prime} 34^{\prime \prime}$ & 13.6 & 8.1 & 4.30 & 96.9 & $<$ d.1. & 0.272 & 22.3 & 118.6 & 4.22 & 6912 \\
\hline $\mathrm{U}-7$ & $\begin{array}{l}\text { Lake Shirokoe } \\
\text { surface }\end{array}$ & 0.5 & $0.6 \mathrm{~km}^{2}$ & $65^{\circ} 49^{\prime} 56.90^{\prime \prime}$ & $75^{\circ} 10^{\prime} 11.17^{\prime \prime}$ & 12.5 & 8.0 & 3.48 & N.D. & $<$ d.l. & 0.243 & N.D. & 10.5 & 0.23 & N.D. \\
\hline $\mathrm{U}-8$ & $\begin{array}{l}\text { Lake Shirokoe } \\
\text { bottom }\end{array}$ & 1.3 & $0.6 \mathrm{~km}^{2}$ & $65^{\circ} 49^{\prime} 56.90^{\prime \prime}$ & $75^{\circ} 10^{\prime} 11.17^{\prime \prime}$ & 12.4 & 9.5 & 3.82 & N.D. & $<$ d.1. & 0.235 & 3.046 & N.D. & N.D. & N.D. \\
\hline U-9 & $\begin{array}{l}\text { Growing lake } \\
\text { surface }\end{array}$ & 0.5 & $20000 \mathrm{~m}^{2}$ & $65^{\circ} 49^{\prime} 54.51^{\prime \prime}$ & $75^{\circ} 11^{\prime} 16.59^{\prime \prime}$ & 12.1 & 10.3 & 4.33 & 18.8 & $<$ d.1. & 0.280 & 0.516 & 33.9 & 1.23 & 2272 \\
\hline U-10 & $\begin{array}{l}\text { Growing lake } \\
\text { bottom }\end{array}$ & 1.5 & $20000 \mathrm{~m}^{2}$ & $65^{\circ} 49^{\prime} 54.51^{\prime \prime}$ & $75^{\circ} 11^{\prime} 16.59^{\prime \prime}$ & 12.1 & 10.3 & 4.33 & 18.7 & 0.000022 & 0.306 & 0.519 & 31.3 & 1.22 & 2010 \\
\hline $\mathrm{U}-11$ & $\begin{array}{l}\text { Lake Yamsovey } 1 \\
\text { stabilized border }\end{array}$ & surface & $0.4 \mathrm{~km}^{2}$ & $65^{\circ} 47^{\prime} 25.89^{\prime \prime}$ & $75^{\circ} 28^{\prime} 00.98^{\prime \prime}$ & 11.9 & 11.4 & 5.01 & N.D. & 0.000022 & 0.203 & 0.439 & 10.3 & N.D. & N.D. \\
\hline $\mathrm{U}-11$ & Lake Yamsovey 1 & 0.5 & $0.4 \mathrm{~km}^{2}$ & $65^{\circ} 47^{\prime} 25.89^{\prime \prime}$ & $75^{\circ} 28^{\prime} 00.98^{\prime \prime}$ & 11.5 & 10.5 & 5.10 & 6.50 & 0.000014 & 0.204 & 0.439 & 12.0 & N.D. & 280 \\
\hline U-11 & Lake Yamsovey 1 & 1.25 & $0.4 \mathrm{~km}^{2}$ & $65^{\circ} 47^{\prime} 25.89^{\prime \prime}$ & $75^{\circ} 28^{\prime} 00.98^{\prime \prime}$ & 11.3 & 10.6 & 5.07 & 6.45 & 0.000014 & 0.210 & 0.441 & 10.2 & 0.29 & 120 \\
\hline $\mathrm{U}-12$ & $\begin{array}{l}\text { Lake Yamsovey 2, } \\
\text { stable borders }\end{array}$ & surface & $1 \mathrm{~km}^{2}$ & $65^{\circ} 44^{\prime} 51.8^{\prime \prime}$ & $75^{\circ} 30^{\prime} 52.3^{\prime \prime}$ & 11.4 & 9.6 & 5.59 & 8.50 & 0.000014 & 0.390 & 0.733 & 11.6 & 0.31 & 100 \\
\hline $\mathrm{U}-13$ & $\begin{array}{l}\text { Lake Khasyrey, } \\
\text { surface }\end{array}$ & 0.5 & $1000 \mathrm{~m}^{2}$ & $65^{\circ} 45^{\prime} 31.5^{\prime \prime}$ & $75^{\circ} 31^{\prime} 03.0^{\prime \prime}$ & 11.7 & 9.8 & 5.72 & 4.50 & 0.000015 & 0.090 & 0.165 & 7.6 & 0.16 & 20 \\
\hline U-13 & $\begin{array}{l}\text { Lake Khasyrey, } \\
\text { water column }\end{array}$ & 1.25 & $1000 \mathrm{~m}^{2}$ & $65^{\circ} 45^{\prime} 31.5^{\prime \prime}$ & $75^{\circ} 31^{\prime} 03.0^{\prime \prime}$ & 11.5 & 9.5 & 5.65 & N.D. & 0.000016 & 0.091 & 0.167 & 8.8 & 0.14 & 80 \\
\hline $\mathrm{U}-13$ & $\begin{array}{l}\text { Lake Khasyrey, } \\
\text { bottom }\end{array}$ & 1.5 & $1000 \mathrm{~m}^{2}$ & $65^{\circ} 45^{\prime} 31.5^{\prime \prime}$ & $75^{\circ} 31^{\prime} 03.0^{\prime \prime}$ & 11.5 & 8.8 & 5.59 & N.D. & 0.000011 & 0.180 & 0.183 & 9.2 & 0.10 & N.D. \\
\hline U-14 & $\begin{array}{l}\text { Lake with stable } \\
\text { border, } \\
\text { macrophytes }\end{array}$ & surface & $0.2 \mathrm{~km}^{2}$ & $66^{\circ} 12^{\prime} 15.9^{\prime \prime}$ & $74^{\circ} 00^{\prime} 41.0^{\prime \prime}$ & 12.4 & N.D. & 5.56 & 4.0 & 0.0000093 & 0.179 & 0.433 & 4.9 & 0.10 & N.D. \\
\hline U-15 & Mature lake & surface & $0.3 \mathrm{~km}^{2}$ & $66^{\circ} 13^{\prime} 05.86^{\prime \prime}$ & $74^{\circ} 02^{\prime} 56.12^{\prime \prime}$ & 12.5 & 9.3 & 6.24 & 10.0 & 0.000044 & 0.445 & 0.512 & 8.4 & 0.28 & N.D. \\
\hline U-16 & Stabilized lake & surface & $0.2 \mathrm{~km}^{2}$ & $66^{\circ} 18^{\prime} 03.25^{\prime \prime}$ & $74^{\circ} 04^{\prime} 23.36^{\prime \prime}$ & 12.2 & N.D. & 5.58 & 8.8 & 0.000041 & 0.237 & 0.194 & 11.6 & N.D. & N.D. \\
\hline $\mathrm{U}-17$ & $\begin{array}{l}\text { Tundra lake } \\
\text { surrounded by bog }\end{array}$ & surface & $0.15 \mathrm{~km}^{2}$ & $66^{\circ} 36^{\prime} 35.7^{\prime \prime}$ & $74^{\circ} 36^{\prime} 35.7^{\prime \prime}$ & 11.5 & 7.8 & 6.76 & 55.5 & 0.000660 & 0.685 & 0.004 & 10.9 & 0.24 & N.D. \\
\hline U-18 & $\begin{array}{l}\text { Youngkhasyrey, } \\
\text { macrophytes }\end{array}$ & surface & $300 \mathrm{~m}^{2}$ & $66^{\circ} 38^{\prime} 02^{\prime \prime}$ & $74^{\circ} 19^{\prime} 51^{\prime \prime}$ & 12.9 & 10.5 & 6.60 & 9.9 & 0.000033 & 0.038 & 0.060 & 17.1 & N.D. & 2 \\
\hline U-19 & $\begin{array}{l}\text { Small spring, } \\
2 \mathrm{~km} \text { length }\end{array}$ & surface & N.D. & $65^{\circ} 52^{\prime} 18^{\prime \prime}$ & $75^{\circ} 07^{\prime} 27^{\prime \prime}$ & 9.0 & 10.2 & 5.10 & 14.9 & 0.000087 & 0.387 & 1.907 & 4.9 & 0.12 & 40 \\
\hline $\mathrm{U}-20$ & $\begin{array}{l}\text { River Yamsovey, } \\
10 \mathrm{~km} \text { length }\end{array}$ & surface & N.D. & $65^{\circ} 51^{\prime} 09^{\prime \prime}$ & $75^{\circ} 23^{\prime} 11^{\prime \prime}$ & 12.3 & 9.7 & 5.09 & 12.0 & 0.000047 & 0.187 & 1.357 & 9.1 & 0.21 & 40 \\
\hline $\mathrm{U}-21$ & $\begin{array}{l}\text { Lake formed after } \\
\text { palsa retreat }\end{array}$ & surface & $2000 \mathrm{~m}^{2}$ & $65^{\circ} 51^{\prime} 59^{\prime \prime}$ & $75^{\circ} 16^{\prime} 96^{\prime \prime}$ & 12.3 & 9.7 & 4.02 & 13.9 & 0.000016 & 0.556 & 0.160 & 23.4 & 0.48 & 35 \\
\hline U-11* & $\begin{array}{l}\text { Lake Yamsovey 1, } \\
\text { melted ice }\end{array}$ & $0.5 \mathrm{~m}$ ice & $0.4 \mathrm{~km}^{2}$ & $65^{\circ} 47^{\prime} 25.7^{\prime \prime}$ & $75^{\circ} 28^{\prime} 01^{\prime \prime}$ & N.D. & N.D. & 4.65 & 5.50 & $<$ d.1. & 0.317 & 0.1465 & 7.03 & 0.11 & N.D. \\
\hline U-12* & $\begin{array}{l}\text { Lake Yamsovey 2, } \\
\text { melted ice }\end{array}$ & $0.5 \mathrm{~m}$ ice & $1 \mathrm{~km}^{2}$ & $65^{\circ} 44^{\prime} 52^{\prime \prime}$ & $75^{\circ} 30^{\prime} 50^{\prime \prime}$ & N.D. & N.D. & 5.49 & 8.10 & N.D. & 0.4894 & 0.712 & 13.06 & N.D. & N.D. \\
\hline U-13* & $\begin{array}{l}\text { Lake Khasyrey, } \\
\text { melted ice }\end{array}$ & $0.5 \mathrm{~m}$ ice & $1000 \mathrm{~m}^{2}$ & $65^{\circ} 45^{\prime} 31.5^{\prime \prime}$ & $75^{\circ} 31^{\prime} 03.0^{\prime \prime}$ & N.D. & N.D. & 5.74 & 4.40 & N.D. & 0.0787 & 0.1197 & 3.03 & 0.05 & N.D. \\
\hline
\end{tabular}

N.D. stands for non-determined;

* stands for sampling in March 2010.

$25^{\circ} \mathrm{C}$ in the dark. Previous studies have shown that culturable bacteria may represent only a small proportion of the species present (the ones that respond well to culture conditions), not necessarily the ones that have an important function in situ, with a possible bias toward rare species (e.g., Pedrós-Alió, 2006). We think that the heterotrophic aerobic bacteria growing on nutrient-rich agar yield the closest culturable approximation to the natural consortia of bacteria present in organic-rich well oxygenated waters of the thermokarst lakes. Culturing bacteria on other types of nutrient media, such as $10 \%$ diluted Nutrient agar and minimal nutrient Bacto oligotrophic agar, yielded similar trends of bacterial number evolution along the chronosequence of lake development (Shirokova et al., 2009).

\section{Results and discussion}

\subsection{Evolution of dissolved organic carbon, eutrophic bacteria and major cations in the sequence of lake development}

The list of sampled lakes and ponds is provided in Table 1, and their location is shown in Fig. 1. Trace element concentration is given in the Supplement (ESM-2). We did not find 


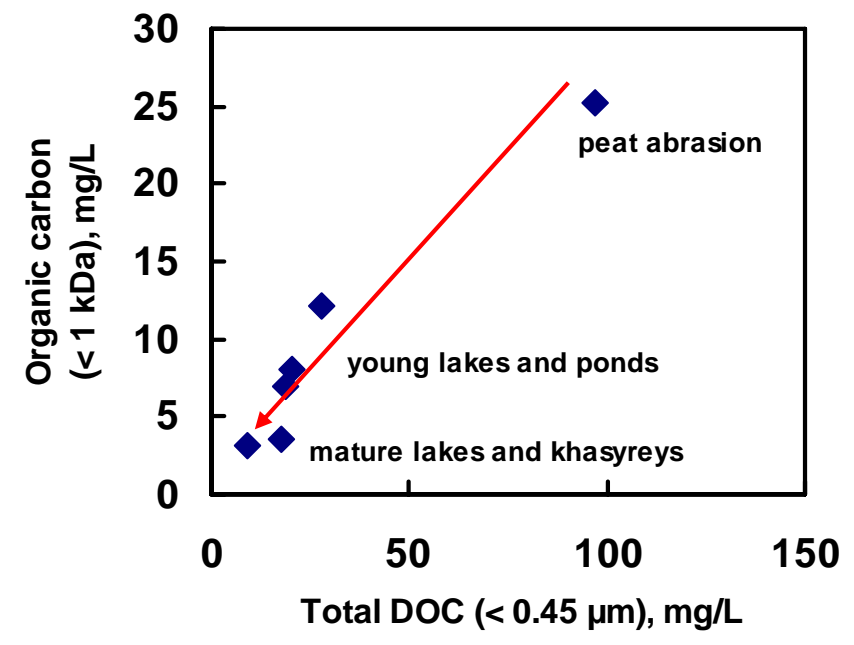

Fig. 4. Concentration of LMW fraction $(<1 \mathrm{kDa})$ of organic carbon as a function of total DOC $(<0.45 \mu \mathrm{m})$.

any measurable chemical and thermal stratification in any of the studied shallow lakes $(0.5-1.5 \mathrm{~m}$ depth). All lakes were close to equilibrium with atmospheric oxygen and values of $\mathrm{pH}$, temperature, concentrations of $\mathrm{O}_{2}, \mathrm{DOC}$, and major and trace elements and were not subject to variation between the surface and bottom horizons (Table 1 and ESM-2). The presence of the anoxic bottom layer was not evident within the resolution of our measurements by the submersible oxygen sensor $( \pm 10 \mathrm{~cm})$. However, our unpublished data on sediments and their pore waters composition for the three lakes of this study (U-1, U-11 and U-13) suggest the presence of a reduced interface at the first $0.5-1.0 \mathrm{~cm}$ of the lake bottom sediments.

The observed chronosequence of the lake ecosystem evolution starts from peat thawing and palsa degradation due to permafrost subsidence in small depressions, continues to shallow ponds and large, $\mathrm{km}$-size lakes and results in the khasyrey (drained lake) formation. Accordingly, there is a systematic decrease of both total $(<0.45 \mu \mathrm{m})$ and truly dissolved low molecular weight $(<1 \mathrm{kDa})$ OC concentrations in the sequence of thermokarst development (Fig. 4). We observed a strong correlation $\left(r^{2}=0.95\right)$ between the DOC $(<0.45 \mu \mathrm{m})$ and UV absorptions at $280 \mathrm{~nm}$, which is considered to be an indicator of humification or aromaticity (Summers et al., 1987; Weishaar et al., 2003; Helms et al., 2008). This correlation strongly suggests a dominantly allochthonous origin (peat soil leaching) of dissolved organic matter at all stages of lake development.

Detailed analysis of OC size fractionation in the course of thermokarst lake development demonstrates a general decrease in the concentration of all fractions of OC $(5 \mu \mathrm{m}$, $0.45 \mu \mathrm{m}, 10 \mathrm{kDa}, 3.5 \mathrm{kDa}$ and $1 \mathrm{kDa}$ ) as illustrated in Fig. 5 . The decrease of the smallest fractions $(3.5 \mathrm{kDa}$ and $1 \mathrm{kDa})$ is more pronounced than that of the larger fractions of DOC; an increase in the $0.45-5 \mu \mathrm{m} \mathrm{OC}$ fraction at the mature lake

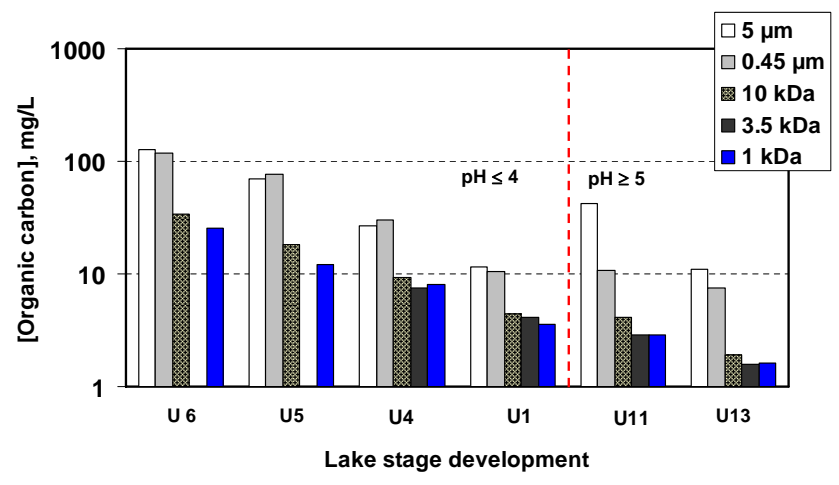

Fig. 5. Concentration of different size fractions of organic carbon (logarithmic scale) in the chronosequence of lake stage development.

stage corresponding to ecosystem stabilization in samples U12 (data not shown in Fig. 5) and U-13 was observed. This increase may be linked to the coagulation and flocculation of organic colloids during bacterioplankton activity known to process colloidal allochthonous OM (e.g., Tranvik et al., 1988) or the experimental biases of filtration through large pore size filters and sample storage. In addition, the increase in the $0.45-5 \mu \mathrm{m}$ OC fraction may stem from the degradation of large planktonic cells, which produce cell fragments in this size range. Exopolymeric substances from phytoplankton and bacteria may also contribute to this increase (Chin et al., 1998; Wilkinson et al., 1997). Finally, the abiotic process of self-organization of dissolved organic matter to micellelike micro particles with a diameter of $0.4-0.8 \mu \mathrm{m}$, which are known to occur in the temperate rivers in autumn (e.g., Kerner et al., 2003), may be responsible for the observed OC size distribution change at these latest stages of lake evolution.

The relative proportion of LMW dissolved OC as a function of conventional DOC $(<0.45 \mu \mathrm{m})$ concentration demonstrates two distinct ranges and increases from 15 to $20 \%$ at the stage of peat abrasion/young ponds and lakes to $28 \pm 5 \%$ for most mature lakes and khasyrey (Fig. 6). We may tentatively attribute this increase to the appearance of small-size autochthonous OC in the form of phytoplankton exometabolites associated with the consumption of allochthonous soilderived $\mathrm{OM}$ by heterotrophic bacterioplankton. In addition to exometabolites production, the higher proportion of LMW carbon in the larger and mature lakes can be a result of the decreasing input of soil and peat-derived organic matter to these lakes, mostly due to a large water-body in relation to the length of the shoreline. Therefore, the average residence time of the allochthonous organic macromolecules in these lakes is longer, exposing them to degradation by the bacterioplankton for a longer time (e.g., Amon and Benner, 1996a, b). As a result, forming macromolecules are smaller in size as compared to those in the smaller, young lakes. Simultaneously, in mature lakes and at the khasyrey stage, the proportion of 


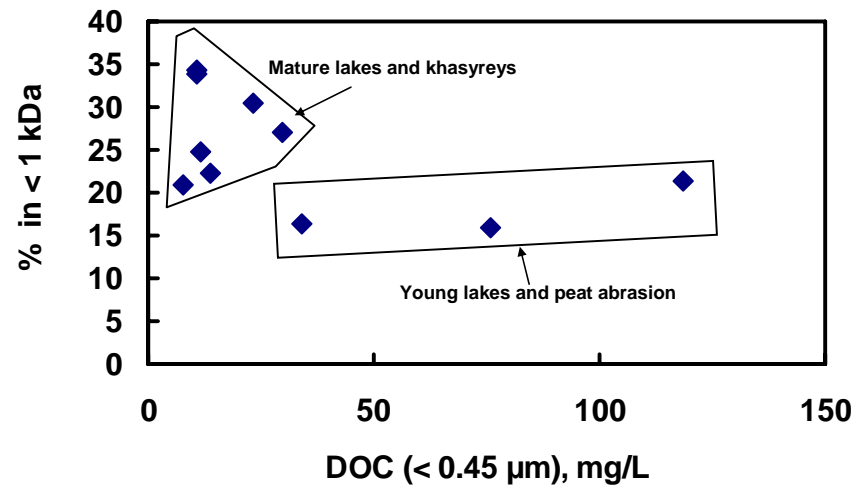

Fig. 6. Proportion of small-size dissolved organic carbon $(<1 \mathrm{kDa})$ as a function of conventional DOC concentration $(<0.45 \mu \mathrm{m})$. Note that at the mature stage of lake development and khasyreys, proportion of small size organic colloids does not depend on total DOC and for most studied lakes it is equal to $27 \pm 5 \%$.

small sized organic macromolecules does not depend on the total DOC and the lake trophic status and can therefore be considered as a representative value for the whole region.

The possible use of small-size organic molecules by the heterotrophic bacterioplankton in growing lakes is illustrated by a plot of LMW ( $<1 \mathrm{kDa}$ ) OC concentration as a function of the number of eutrophic bacteria that exhibits a $\mathrm{r}^{2}$ value of 0.91 (Fig. 7a). This relationship is also maintained for conventional dissolved $(<0.45 \mu \mathrm{m})$ organic carbon (Fig. $7 \mathrm{~b})$ although the correlation coefficient is smaller $\left(r^{2}=0.82\right)$. This evolution can be explained by the use of allochthonous OM and dissolved nutrients originating from peat lixiviation by the heterotrophic microbial community of the lake water column. It should be noted that for mature lakes and khasyreys, there is a certain contribution of LMW OM from the phytoplankton that results in producing fresher OM as compared to the refractory soil-derived fraction that is easily respired by the bacterioplankton. In addition to the pelagic respiration of DOC, benthic respiration and dissolved organic matter (DOM) photolysis are known to be important factors in controlling $\mathrm{OM}$ degradation and $\mathrm{CO}_{2}$ release into the atmosphere by the boreal lakes (e.g., Jonsson et al., 2001, 2008) with even the much larger contribution of benthic respiration occurring in shallow ponds (Kortelainen et al., 2006). However, given similar depth of all studied lakes, we do not expect significant variations in the relative intensity of benthic respiration over the course of lake chronosequence development. In contrast, the longer residence time of water in large lakes may increase the photodegradation of OM at the latest stage of lake development. In addition, water column transparency to solar radiation will also increase with a decrease in DOM concentration (and color). It is important to note that the values of bacterial respiration in all of the studied lakes measured using dark bottle incubation are close to $1 \mu \mathrm{M} \mathrm{Chr}^{-1}$ (Shirokova et al., 2009), which is of the
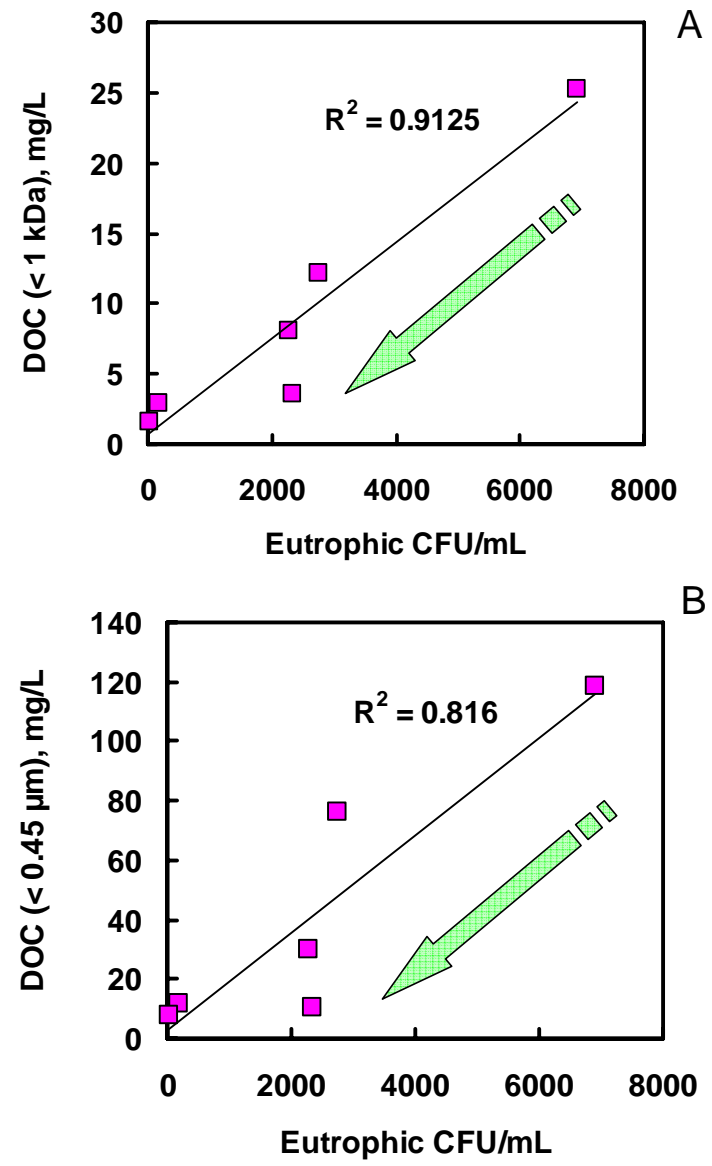

Fig. 7. Concentration of LMW fraction $(<1 \mathrm{kDa}$; $\mathbf{A})$ and conventionally dissolved $(<0.45 \mu \mathrm{m} ; \mathbf{B})$ organic carbon as a function of active culturable heterotrophic bacteria (Colony Forming Units/mL). Arrow indicates the lake stage evolution, from peat abrasion, young lakes and ponds to mature lakes and khasyreys.

same order of magnitude as the rate of DOC photo-oxidation in organic-rich and peat waters ( 1 to $4 \mu \mathrm{MC} \mathrm{hr}^{-1}$, De Haan, 1993; Amon and Benner, 1996b). Given that photochemical processes degrade a part of the refractory pool of DOM that is not readily available to bacteria (Amon and Benner, 1996b), the importance of photodegradation in thermokarst lakes deserve further investigation.

A specific and unique feature of the studied systems is that dissolved "trace metals" such as $\mathrm{Al}$ and Fe are the major components of western Siberian thermokarst lakes. Plotted in Fig. 8 are the correlations of $\mathrm{Fe}$ and $\mathrm{Al}$ with DOC in the $<0.45 \mu \mathrm{m}$ fraction $\left(r^{2}=0.835\right.$ and 0.837 , respectively). As shown in this figure, the typical concentrations of these metals range from 0.1 to $1 \mathrm{mg} \mathrm{L}^{-1}$, which is higher than the concentration of other major elements, such as $\mathrm{Mg}, \mathrm{K}$, and $\mathrm{Si}$ (cf. Table ESM-2). These concentrations are much higher as compared to the following: (1) typical river and lake water metal concentrations all over the world (Gaillardet et al., 2003); (2) Al, Mn and Fe concentrations in the water column 
A
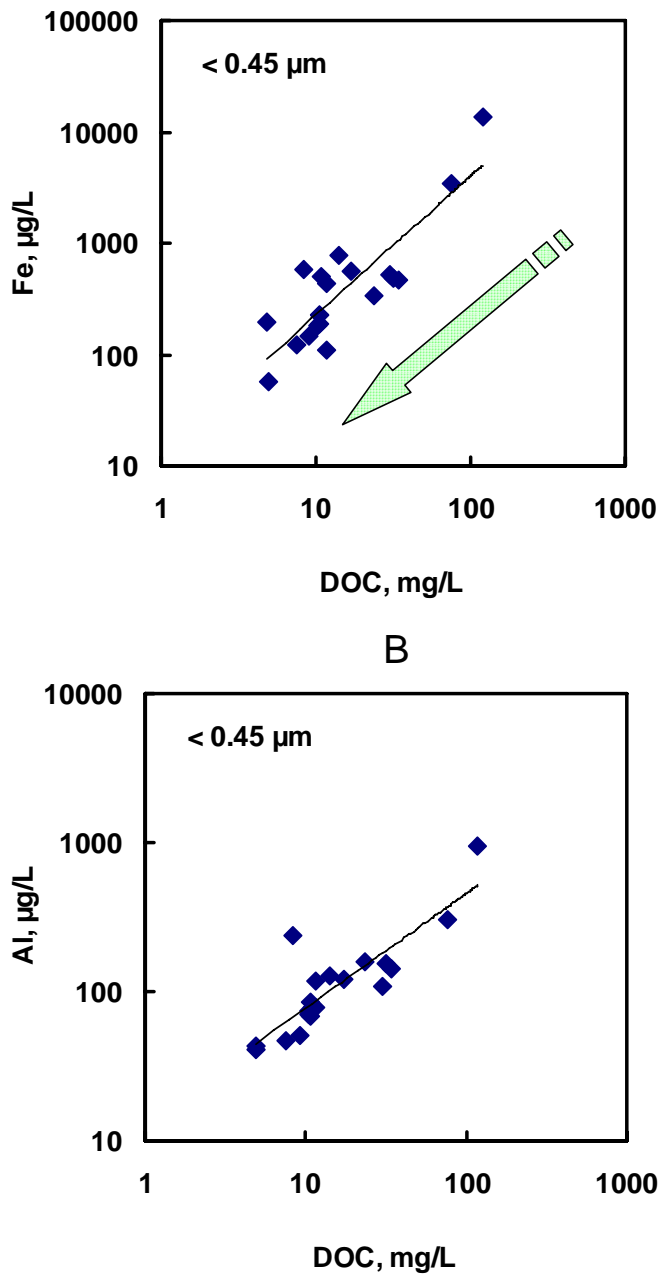

Fig. 8. Concentration of $\mathrm{Fe}(\mathbf{A})$ and $\mathrm{Al}(\mathbf{B})$ as a function of Dissolved Organic Carbon (DOC) in $<0.45 \mu \mathrm{m}$ fraction of various lakes and ponds. Arrow indicates the lake stage evolution, from peat abrasion, young lakes and ponds to mature lakes and khasyreys.

of the Imandra Lake of the Kola Peninsula $(8,10-22$, and $17 \mu \mathrm{g} \mathrm{L}{ }^{-1}$, respectively, Ingri et al., 2011); (3) metal concentrations in the lakes of Canada's Northwestern Territories (Pienitz et al., 1997a, b; Rühland and Smol, 1998; Lim et al., 2005; Côté et al., 2010), the Canadian High Arctic (Lim et al., 2001; Michelutti et al., 2002a, b; Antoniades et al., 2003) and arctic Alaska (Kling et al., 1992); and (4) the chemical composition of lakes in central Yakutia (Kumke et al., 2007; Wetterich et al., 2008) and northern Eurasia (Duff et al., 1999; Solovieva et al., 2005). We propose that the observed composition of the lake water stems from the weathering of significantly altered Neogene sands underlying the podzols and acid peat soils that are poor in $\mathrm{Na}, \mathrm{Ca}$ and $\mathrm{Mg}$, and enriched in $\mathrm{Al}$ and $\mathrm{Fe}$. Additional factors responsible for enhanced $\mathrm{Fe}$ and $\mathrm{Al}$ mobility in the studied waters were the presence of $\mathrm{Al}$ and $\mathrm{Fe}$ in partially ionic forms at low $\mathrm{pH}$ and a high concentration of DOM-stabilizing $\mathrm{Fe}$ and $\mathrm{Al}$ colloids at an elevated $\mathrm{pH}$. This high mobility of usually "immobile" elements is further illustrated by a comparison of dissolved and colloidal element concentration ratios (Fe/Al, 3 to $10 ; \mathrm{Ca} / \mathrm{Al}$, 2 to 7 ; Ti/Al, 0.01 to 0.03 , and $\mathrm{Zr} / \mathrm{Al}, 0.001$ to 0.003 ) to those measured in the soil profile of unfrozen peat $(\mathrm{Fe} / \mathrm{Al}, 1.5-$ 3.5; $\mathrm{Ca} / \mathrm{Al}, 0.5$ to 1.5 ; Ti/Al, 0.05 to 0.07 , and $\mathrm{Zr} / \mathrm{Al}, 0.002$ to 0.003$)$. The similarity of these ratios demonstrates relatively low fractionation of chemical elements between the surface fluids and the source material. Unlike rivers draining the mineral bedrock, the water in the lakes and ponds located within the frozen peat terrain is unlikely to bear a signature of mineral horizons, being completely dominated by the dissolution of peat organic material.

Similar to OC, there is a systematic decrease of $\mathrm{Fe}$ and $\mathrm{Al}$ concentration from the beginning of lake formation toward mature ecosystems. According to their affinity to $\mathrm{Fe}, \mathrm{Al}$ or DOC, several groups of major and trace elements can be distinguished. There are elements whose concentrations are indifferent to the stage of lake development. Typical elements of this group are anions, such as $\mathrm{Cl}^{-}, \mathrm{SO}_{4}^{2-}, \mathrm{Mo}, \mathrm{Sb}$, and As, and elements present in the form of neutral molecules, such as $\mathrm{Si}, \mathrm{Ge}$, alkali ( $\mathrm{Li}, \mathrm{Na}, \mathrm{K}, \mathrm{Cs}$ ) and alkaline earth metals $(\mathrm{Mg}, \mathrm{Ca})$, that do not exhibit any correlation with $\mathrm{Fe}$ or DOC. Significant correlation with DOC is observed only for $\mathrm{Cu}, \mathrm{Pb}$, and $\mathrm{Cd}$, whereas most insoluble trace metals are better correlated with $\mathrm{Fe}$ or $\mathrm{Al}$ than with the DOC: $\mathrm{V}, \mathrm{Cr}, \mathrm{Mn}, \mathrm{Co}, \mathrm{Ni}, \mathrm{Sr}, \mathrm{Ba}, \mathrm{Ga}, \mathrm{Y}, \mathrm{REEs}, \mathrm{Zr}, \mathrm{Hg}$, Th, and U. Examples of these correlations are illustrated in Fig. ESM-3 of the Supplement. Most lakes exhibit extremely high concentrations of insoluble and immobile elements, such as $\mathrm{Ti}$ and $\mathrm{Zr}$ (1-10 and $0.1-1 \mu \mathrm{g} \mathrm{L}^{-1}$, respectively). These values are at least two orders of magnitude higher than the average concentration of these elements in continental waters and Siberian rivers (Gaillardet et al., 2003; Pokrovsky et al., 2006). Such high concentrations of insoluble TEs stem from the following: (1) low $\mathrm{pH}$, especially at the beginning of lake formation, which stabilizes trivalent ions in the form of free ions in accordance with the well-known correlation between REE concentration and solution acidity (Johannesson and Zhou, 1999; Johannesson et al., 2004); and (2) high DOC and Fe concentration rendering these elements to the form of organo-mineral colloids as shown by the size-separation procedure and discussed in the following sections. A good correlation maintained over two orders of magnitude between $\mathrm{Co}$ and $\mathrm{Mn}$ concentration in all the studied lakes and ponds had a ${ }^{2}$ value of 0.861 (Fig. 9). This value may reflect a functional dependence of the adsorbed and coprecipitated Co scavenging with Mn oxy(hydr)oxides in the water column as it is known for stratified temperate lakes (Hamilton-Taylor et al., 2005). In thermokarst lakes, this functional relationship may be linked to the mineralization of organic material by heterotrophic bacterioplankton at the young stage of lake development and/or diffusion of $\mathrm{Mn}$ from the sediments to the water column at the mature stage, followed by the 


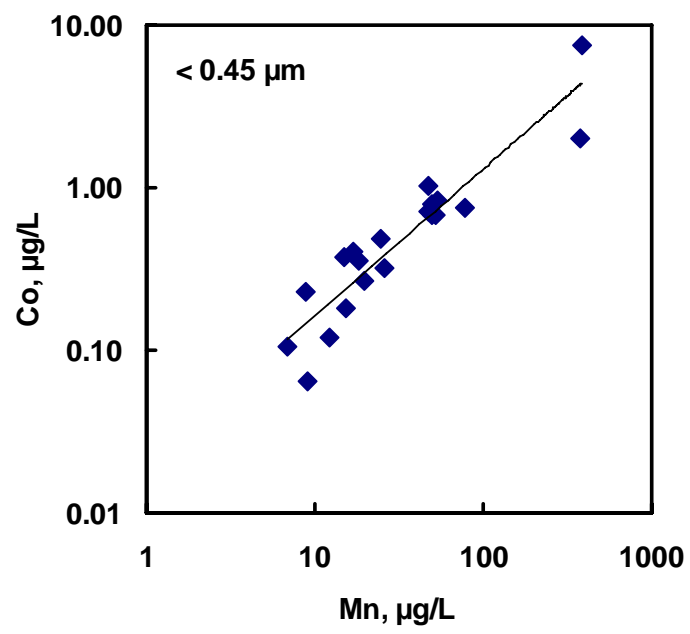

Fig. 9. Concentration of $\mathrm{Co}$ as a function of $\mathrm{Mn}$ concentration in $<0.45 \mu \mathrm{m}$ fraction of various lakes and ponds.
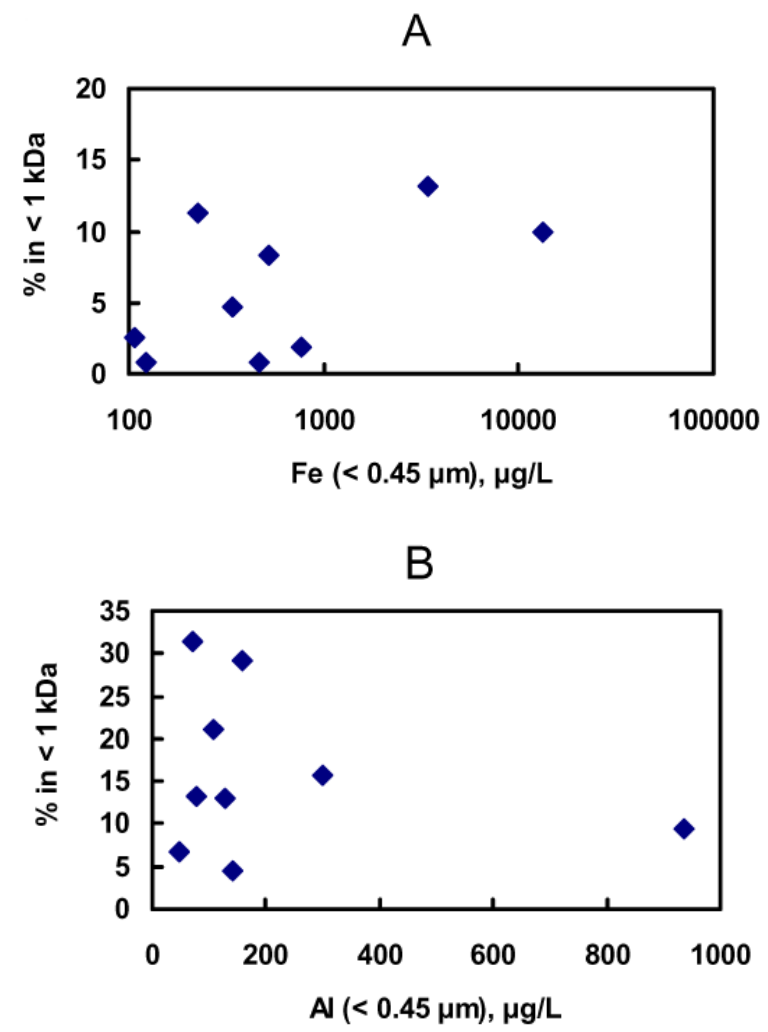

Fig. 10. Relative proportion of LMW of $\mathrm{Fe}(\mathbf{A})$ and $\mathrm{Al}(\mathbf{B})$ as a function of total dissolved $(<0.45 \mu \mathrm{m})$ metals in all lakes and ponds. The average concentration of $<1 \mathrm{kDa}$ fraction is equal to $6 \pm 4 \%$ and $14 \pm 6 \%$ for $\mathrm{Fe}$ and $\mathrm{Al}$, respectively.

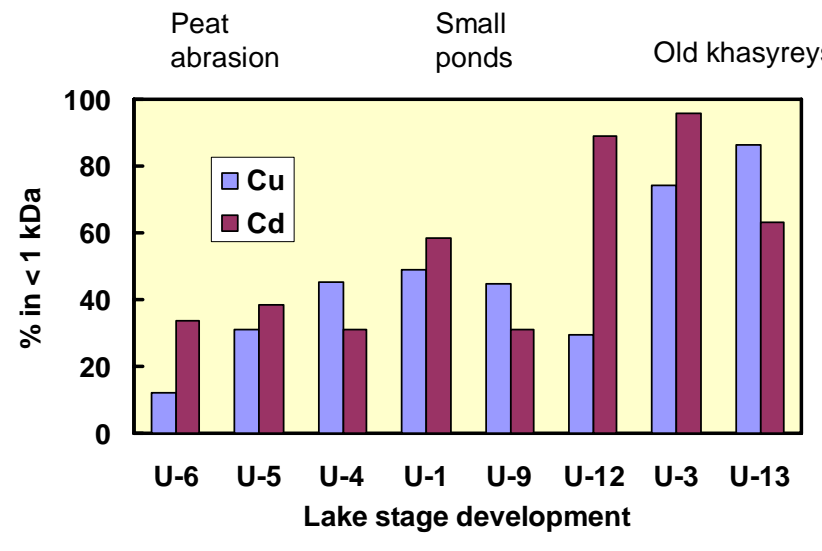

Fig. 11. Stack diagram of $\mathrm{Cu}$ and $\mathrm{Cd}$ proportion in the form of small-size complexes and ions $(<1 \mathrm{kDa})$ in lakes and ponds along the chronosequence of lake development. There is an increase of small size organic ligands binding divalent metals produced by the phytoplankton at the mature stage of ecosystem development at the expense of bacterioplankton mineralization of large colloidal size allochthonous humic and fulvic complexes.

oxidation at the oxic front of bottom water horizons. In nonpermafrost lakes, the biological precipitation of dissolved $\mathrm{Mn}$, and the sedimentation and mineralization of the nondetrital Mn phase in the lake sediments resulting in a steady increase of dissolved $\mathrm{Mn}$ concentration is fairly well known (e.g., Pontér et al., 1992).

\subsection{Proportion of organic carbon and trace elements in "truly dissolved" LMW ( $<1 \mathrm{kDa})$ fraction}

The dialysis procedure employed in the present study allowed for a quantitative assessment of the proportion of colloidal $(1 \mathrm{kDa}-0.45 \mu \mathrm{m})$ and "truly dissolved" LMW $(<1 \mathrm{kDa})$ element concentration in order to establish a link between these parameters and major solution parameters, such as [DOC] and $\mathrm{pH}$. We found that the proportion of LMW $\mathrm{Fe}$ and $\mathrm{Al}$ do not depend on the lake stage development or the concentration of these metals in the $<0.45 \mu \mathrm{m}$ fraction as shown in Fig. 10a, b. The average proportion of the $<1 \mathrm{kDa} \mathrm{Fe}$ and $\mathrm{Al}$ fraction is equal to $6 \pm 4$ and $14 \pm 6 \%$, respectively. Such an independence of the proportion of the $<1 \mathrm{kDa}$ LMW fraction on lake stage development (or the $<0.45 \mu \mathrm{m}$ element concentration) is observed for most trace metals except those that are strongly bound to biological ligands, such as $\mathrm{Cu}$ and $\mathrm{Cd}$. For these elements, there is a general increase in the small-size fraction $(<1 \mathrm{kDa})$ with lake stage evolution, from peat abrasion and small ponds to mature lakes and old khasyreys as illustrated in the form of a stack diagram in Fig. 11. We tentatively interpret this evolution as being related to an increase in the proportion of small size organic ligands produced by phytoplankton at the expense of large-size organic (humic and fulvic) complexes of allochthonous origin, which are being mineralized by the 


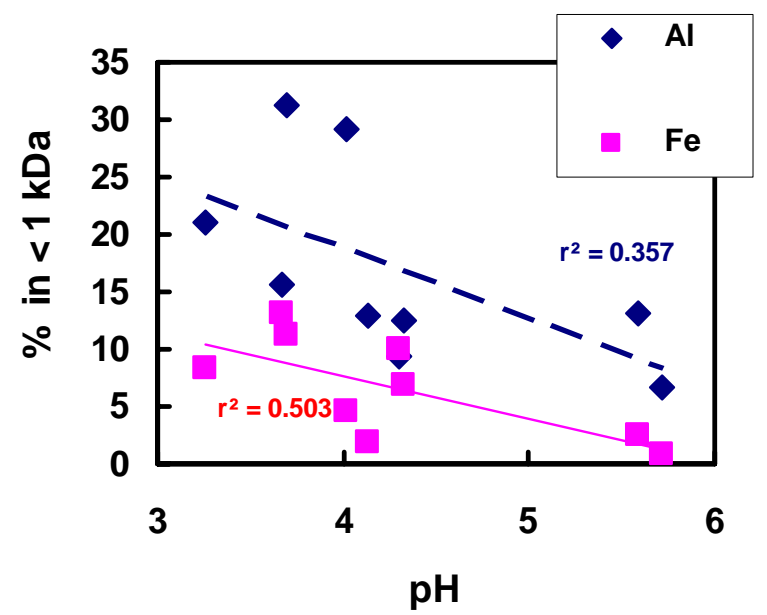

Fig. 12. Relative proportion of small-size fraction of Fe (A) and $\mathrm{Al}(\mathbf{B})$ as a function of solution $\mathrm{pH}$ in lakes and ponds.

heterotrophic bacterioplankton. However, such small-size strong ligands are fairly known for $\mathrm{Cu}$ in freshwaters and are most likely related to phytoplankton (e.g., Xue and Sigg, 1993; Wu and Tanoue, 2001). Simultaneously, because fulvic acids are only a few $\mathrm{nm}$ in size (e.g., $1.5-2.5 \mathrm{~nm}$, Lead et al., 2000), significant parts of soil-derived organic matter are found in the $1 \mathrm{kDa}$ dialysate. The divalent metals such as $\mathrm{Cd}$ and $\mathrm{Cu}$ form strong complexes with LMW ligands and, thus, do not follow the pattern of colloidal $\mathrm{Fe}$ and $\mathrm{Al}$ oxy(hydr)oxides similar to other insoluble TEs. Photoreduction is another possible reason for the appearance of small organic ligands. Undeniably, in this type of water (oxygen saturation, low $\mathrm{pH}$, high $\mathrm{Fe}$ and DOC concentration), photoreduction of organic bound $\mathrm{Fe}$ (III) should be important for the following reasons: (i) strong insulation due to the Arctic summer and the absence of forests; and (ii) shallow depths of all the studied lakes $(0.5-1.5 \mathrm{~m})$.

We found that solution $\mathrm{pH}$ exerts certain control on the $\mathrm{Fe}$ and $\mathrm{Al}$ fractionation between colloidal and conventionally dissolved $(<1 \mathrm{kDa})$ pools. This is illustrated in Fig. 12 where the percentage of $\mathrm{Fe}$ and $\mathrm{Al}$ in the $<1 \mathrm{kDa}$ fraction is plotted as a function of $\mathrm{pH}$. There is a decreasing tendency of truly dissolved metals in proportion to the $\mathrm{pH}$. Although $\mathrm{Fe}$ is less affected by $\mathrm{pH}$ change as compared to $\mathrm{Al}$ (slopes equal to 3.7 and 6.1, respectively), the correlation coefficient is larger for $\mathrm{Fe}$ as compared to $\mathrm{Al}(0.503$ and 0.357 , respectively). These positive correlations may reflect an increase in the complexation of metals with large-size organic ligands during their progressive deprotonation in the course of $\mathrm{pH}$ increase. The opposite tendency is the competition of hydroxyl ions with organic colloids for metal binding at $\mathrm{pH}>4-5$, which should increase the proportion of small-size ions and molecules. Some strongly-bound organic ligands may be present in the $<1 \mathrm{kDa}$ fraction in which the OC concentration is between 15 and $35 \%$ of that in the $<0.45 \mu \mathrm{m}$ fraction.

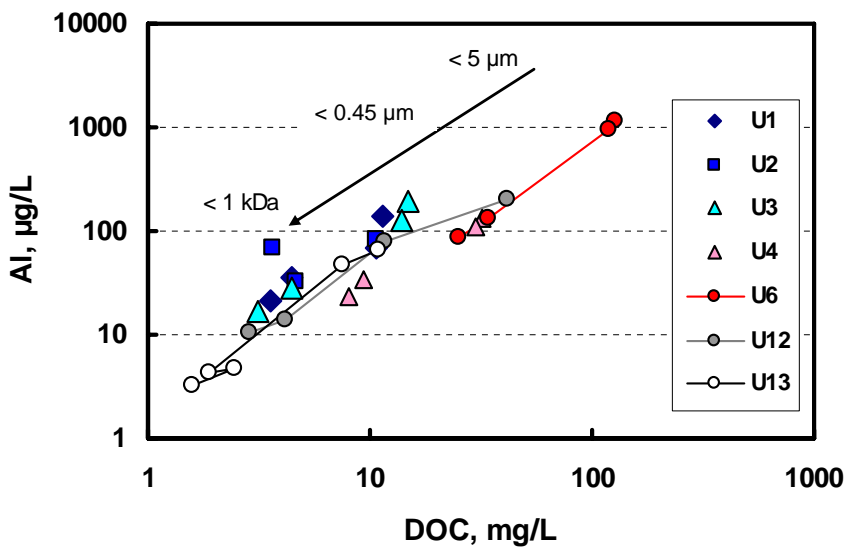

Fig. 13. Correlation between $\mathrm{Al}$ and $\mathrm{DOC}$ in filtrates and dialysates of various samples shown by different symbols (see Table 1 for description). In each series, the first (highest) point corresponds to filtration through 5 or $0.45 \mu \mathrm{m}$ and the lowest point represents dialysis through $1 \mathrm{kDa}$.

\subsection{Size fractionation of major and trace elements during filtration and dialysis}

Major and trace element concentration in the filtrates and dialysates of all samples are listed in Table ESM-2 of the Supplement. Similar to DOC, concentrations of Fe and Al decrease drastically during the size separation procedure. $\mathrm{Fe}$ and $\mathrm{Al}$ are present in the form of large-size colloids $(0.45 \mu \mathrm{m}-10 \mathrm{kDa})$, and they are essentially removed from the solution before dialysis through 10 and $1 \mathrm{kDa}$ membranes, as only 10 to $30 \%$ of these metals are concentrated in the $<1 \mathrm{kDa}$ fraction. Figure 13 presents an example of the filtration and dialysis patterns of $\mathrm{Al}$ in various lakes and ponds along with the stages of chronosequence. As shown in this figure, all samples are clustered within the same trend line as defined by the decreasing pore size from $<5 \mu \mathrm{m}$ fraction to $<1 \mathrm{kDa}$ fraction.

Among the major elements, dissolved silica concentration is least influenced by the filtration and dialysis procedures. Within the uncertainty of $10 \%$, we could not detect any difference between the Si concentrations in various filtrates from $5 \mu \mathrm{m}$ to $1 \mathrm{kDa}$, even at the beginning of lake formation (peat abrasion) in an organic-rich pond (DOC $\sim 120 \mathrm{mg} \mathrm{L}^{-1}$ ). This result indicates the absence of smallsized phytolithes, clays or silica-rich organic debris in these waters and suggests that most of the aqueous silica is not associated with colloids. Concentrations of alkali ( $\mathrm{Li}, \mathrm{Na}, \mathrm{K}$, $\mathrm{Rb}$ ) do not change by more than $20-30 \%$ between size fractions ranging from $0.45 \mu \mathrm{m} \mathrm{kD}$ to $1 \mathrm{kD}$. At the same time, it is noteworthy that significant proportions of colloidal $\mathrm{Ca}$, $\mathrm{Sr}$, and $\mathrm{Ba}$ are present at all stages of lake evolution, from 30 to $50 \%$ (Table ESM-2). Colloidal alkaline earth metals in organic-rich surface boreal waters have been reported by Dahlqvist et al. (2004) and recently confirmed by Pokrovsky et al. (2010). 


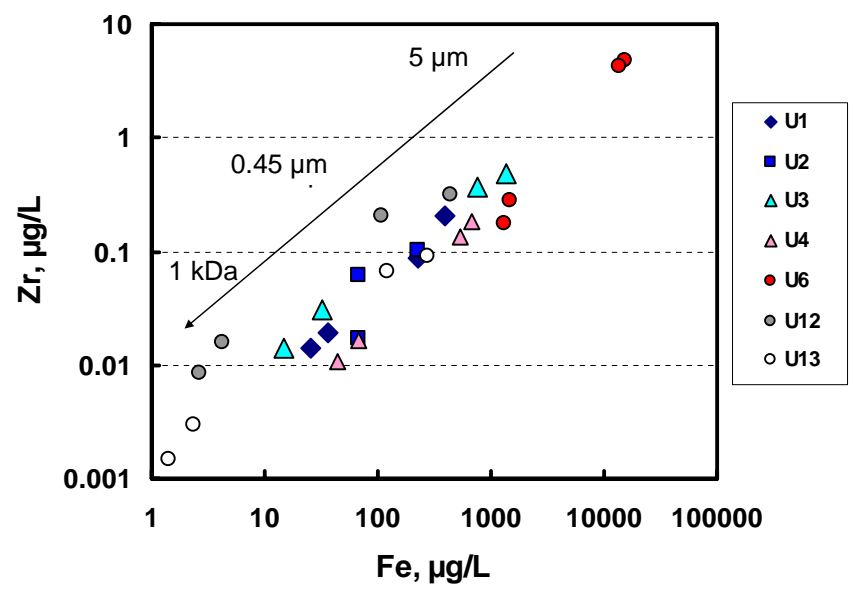

Fig. 14. Correlation between $\mathrm{Zr}$ and $\mathrm{Fe}$ in filtrates and dialysates of various samples shown by different symbols. In each series, the first (highest) point corresponds to filtration through 5 or $0.45 \mu \mathrm{m}$ and the lowest point represents dialysis through $1 \mathrm{kDa}$.

Concentrations of $\mathrm{V}, \mathrm{As}, \mathrm{Se}, \mathrm{Nb}, \mathrm{Mo}, \mathrm{Sn}$ and $\mathrm{Sb}$ remain stable during the filtration and dialysis procedures and do not exhibit a clear correlation with dissolved Fe or DOC. Concentrations of divalent transition metals decrease during filtration and dialysis in parallel with that of DOC as illustrated for Mn in the Supplement (ESM-4) (Fig. ESM-4C). In fact, more than $90 \%$ of $\mathrm{Mn}^{2+}$ is in the form of $1 \mathrm{kDa}-$ $0.45 \mu \mathrm{m}$ organic colloids. This finding may explain the progressive decrease of $\mathrm{Mn}$ concentration along the sequence of lake development accompanied by a ten-fold decrease in [DOC] (Fig. 4). Trivalent, tetravalent elements and uranium exhibit a strong affinity for colloidal fraction in sampled waters. Typically, more than $80 \%$ of REEs are concentrated in the $>1 \mathrm{kD}$ fraction, and more than half of these elements are associated with large-size colloids ( $10 \mathrm{kDa}$ to $0.45 \mu \mathrm{m})$. The relative proportion of heavy REE in the $<1 \mathrm{kDa}$ versus the $<0.45 \mu \mathrm{m}$ fraction is a factor of 2 to 3 higher than that of light REE (Table ESM-2). This finding is consistent with previously studied granite and basalt-dominated catchments (Ingri et al., 2000; Pokrovsky and Schott, 2002; Pokrovsky et al., 2006), tropical watersheds (Dupré et al., 1999; Eyrolle et al., 1996) and groundwater (Dia et al., 2000) and most likely linked to the preferential affinity of light REE, such as $\mathrm{La}$, to colloidal organo-mineral surfaces and the tendency of heavy REE, such as $\mathrm{Yb}$, to form stable solution complexes (i.e., Sholkovitz, 1995; Johannesson et al., 2004).

Insoluble tetravalent elements ( $\mathrm{Ti}, \mathrm{Zr}$, Hf and $\mathrm{Th}$ ) systematically decrease their concentration upon dialysis and filtration, exhibiting a good positive correlation between $\left[\mathrm{TE}^{4+}\right]$ and $[\mathrm{Fe}]\left(0.93 \leq R^{2} \leq 0.99\right)$ as illustrated for $\mathrm{Zr}$ in Fig. 14. It is important to note that along with the filtration and dialysis patterns, all samples demonstrate the same slope between the concentrations of TEs and Fe or DOC. This slope is approximately 1 and 0.5 for $\mathrm{Fe}$ and DOC, respectively.

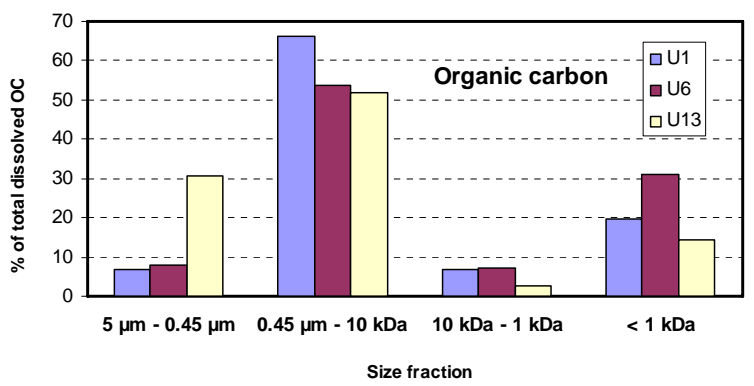

A

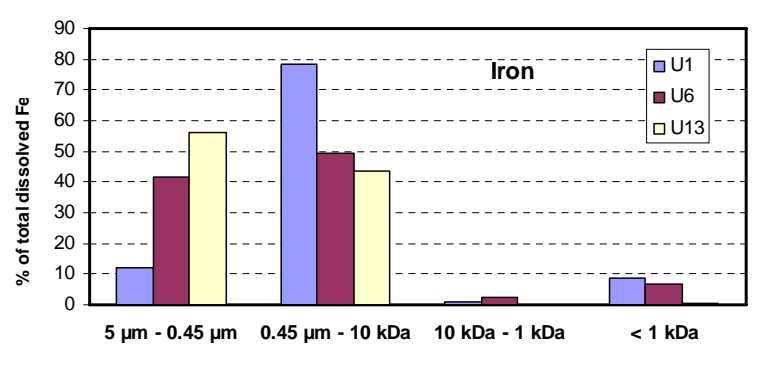

B

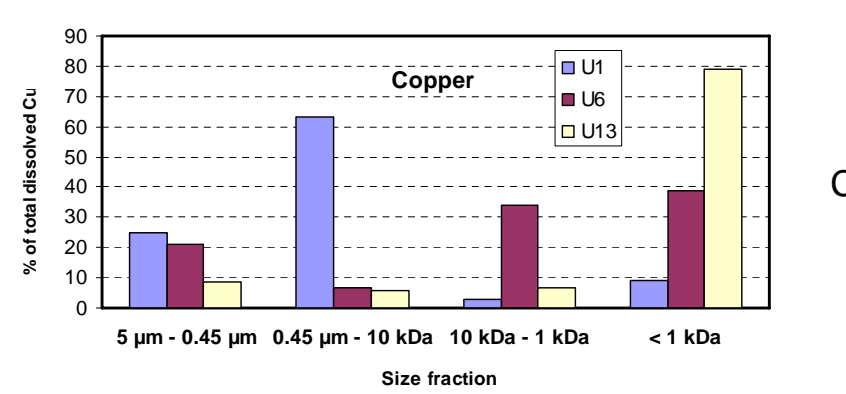

Fig. 15. Size fractionation of $\mathrm{OC}(\mathbf{A}), \mathrm{Fe}(\mathbf{B})$ and $\mathrm{Cu}(\mathbf{C})$ among main colloidal and subcolloidal fractions in typical samples reflecting three main stages of thaw lake development: U-6, U-1 and U-13 corresponding to peat abrasion, large growing lake and final (khasyrey stage) of the lake.

To better illustrate the size fractionation scheme for the different elements, we present a histogram of $\mathrm{OC}, \mathrm{Fe}$ and $\mathrm{Cu}$ distribution between the following four colloidal and sub colloidal fractions: $5-0.45 \mu \mathrm{m}, 0.45 \mu \mathrm{m}-10 \mathrm{kDa}, 10 \mathrm{kDa}-1 \mathrm{kDa}$, and $<1 \mathrm{kDa}$ for the three principal stages of lake development (Fig. 15a-c). It can be seen that for Fe, large-size particles (between 5 and $0.45 \mu \mathrm{m})$ and colloids $(0.45-10 \mathrm{kDa}$ ) are the main constituents of the dissolved load. Similar size fractionation is observed for $\mathrm{Al}$ and other insoluble trivalent and tetravalent elements. In contrast, at the late mature stage of lake development or khasyrey (sample U-13), small size colloidal and truly dissolved fractions $(1-10 \mathrm{kDa},<1 \mathrm{kDa})$ become significant for $\mathrm{Cu}$, which may be strongly affected by the phytoplankton exometabolites or LMW complexes with fulvic acids (Fig. 15c).

Further insights on sub-colloidal versus truly dissolved (LMW) fraction evolution among different types of the studied ecosystems can be assessed from the analysis of the ratio $[5-0.45 \mu \mathrm{m}]$ fraction to $[<1 \mathrm{kDa}]$ fraction (Fig. 16). 

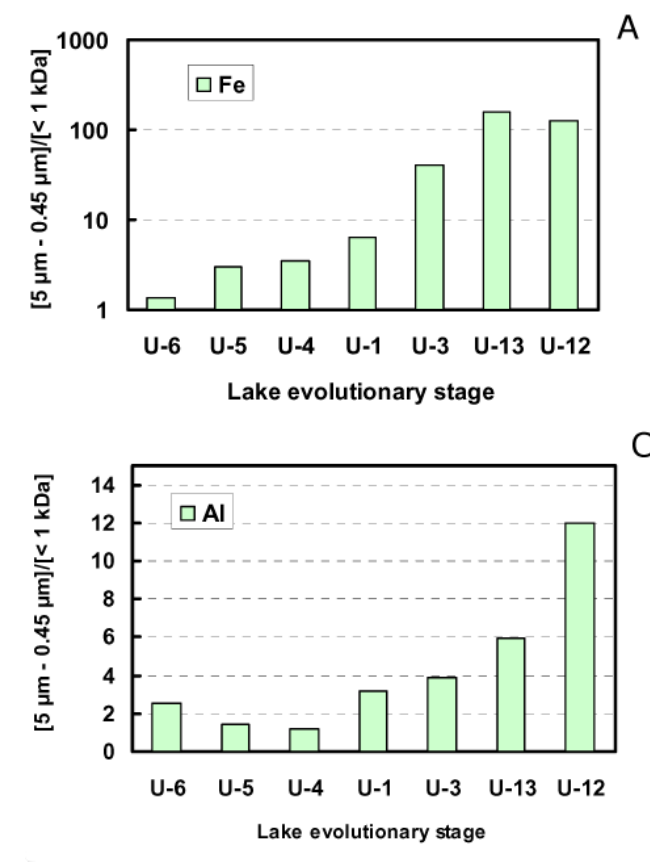
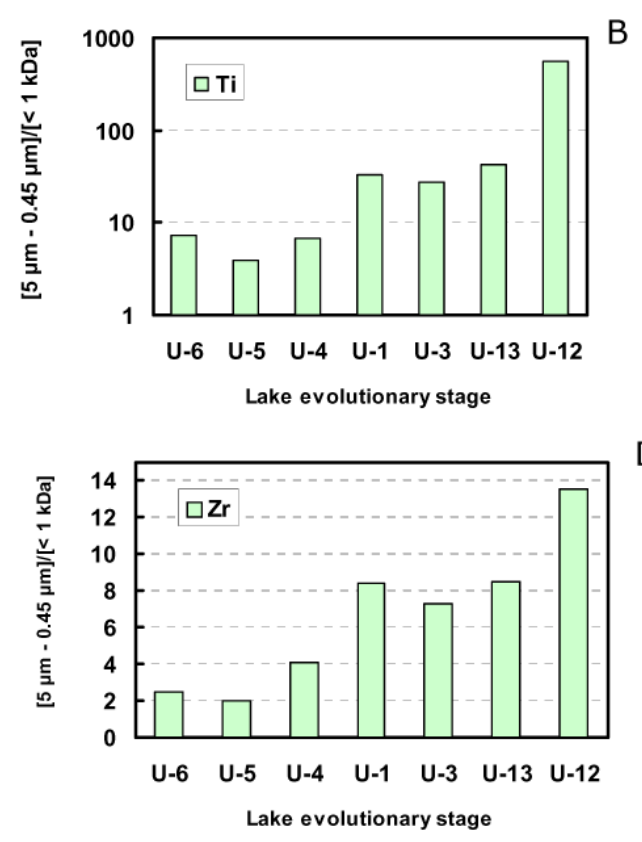

D

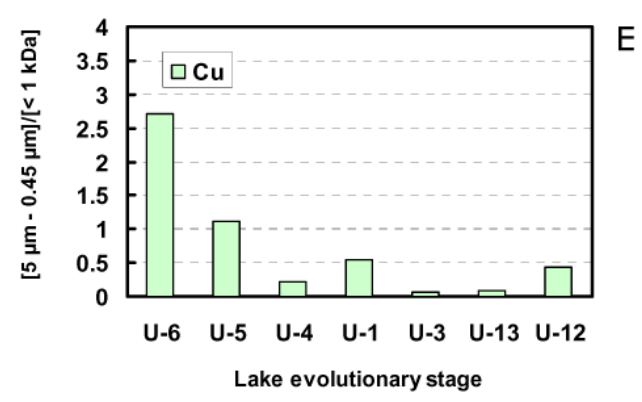

Fig. 16. Colloidal reorganization in the course of lake evolution: the increase of the relative proportion of large-size $\mathrm{Fe}(\mathrm{Al}) \mathrm{sub}-\mathrm{colloids} /$ particles with lake chronosequence development. It is possible that the heterotrophic bacteria uptake DOC $(<0.45 \mu \mathrm{m})$, liberate $\mathrm{Fe}(\mathbf{A}), \mathrm{Al}(\mathbf{C})$ mineral colloids that are aggregating in subcolloidal/particles thus tranforming size dsitribution of related trace elements: Ti (B), $\mathrm{Zr}(\mathbf{D})$ and $\mathrm{Cu}$ (E).

This ratio reflects the relative contribution of the suspended, non-silicate (particulate) fraction to the truly dissolved (low molecular weight) element fraction. There is a systematic increase in the ratio of particulate to LMW fraction along the chronosequence of lake stage development, from peat abrasion to mature ecosystems. We tentatively interpret this evolution as a process of on-going colloidal coagulation linked to the activity of heterotrophic bacterioplankton. Heterotrophic bacteria consume colloidal $(<0.45 \mu \mathrm{m})$ and dissolved ( $<1 \mathrm{kDa}$ ) organic carbon (Fig. 7) as shown by the net heterotrophic status of all the lakes (Shirokova et al., 2009), thus liberating $\mathrm{Fe}, \mathrm{Al}$, mineral colloids and associated insoluble metals. In the course of progressive coagulation of large-size Fe-Al colloids, we observed a systematic increase in their relative proportion in the water column (Fig. 16a, c). Insoluble elements such as $\mathrm{Ti}$ or $\mathrm{Zr}$ carried by the Fe-Al colloids and particles follow this tendency (Fig. 16b, d). In contrast, for $\mathrm{Cu}$, which may be strongly linked to small-size microbial and phytoplankton exudates, the relative role of LMW species increases over the course of lake stage development (Fig. 16e). For this element, the ultra filterable $(<3 \mathrm{kDa})$ organic ligand stability constants are reported to be significantly stronger than those of $0.40 \mu \mathrm{m}$ filterable fraction of freshwater (Hoffmann et al., 2007), thus confirming the high affinity of $\mathrm{Cu}$ to small-size organic ligands. This finding is also in agreement with the results of size fractionation in temperate rivers (Stolpe et al., 2010). The increase in the fraction $0.45-5 \mu \mathrm{m}$ organic matter along the ecosystem stabilization trend may stem from the appearance of biopolymers and other organic matter from phytoplankton, which could further contribute to the coagulation of colloidal $\mathrm{Fe}$ and $\mathrm{Al}$ (Wilkinson et al., 1997; Perret et al., 2000). 


\subsection{Colloidal speciation modeling}

Considering the high concentrations of $\mathrm{Fe}$ and $\mathrm{Al}$ in $<0.45 \mu \mathrm{m}$ fraction observed in the studied lakes, it is reasonable to assume that these metals are the major mineral constituents of colloids. Trace metals, notably trivalent and tetravalent elements, and uranium associated with these organo-mineral colloids may be present in the following three forms: (i) complexed with organic ligands of the organic part of the colloids, (ii) adsorbed at the surface of colloidal particles, and (iii) incorporated in the bulk of $\mathrm{Fe}(\mathrm{Al})$ rich colloids stabilized (coated) by $\mathrm{OM}$ as reported in previous studies (Ingri et al., 2000; Dia et al., 2000; Andersson et al., 2006). The results of the present study corroborate recent research on colloidal size fractionation in temperate rivers and coastal waters that show the presence of small $0.5-3 \mathrm{~nm}$ spherical organic-matter colloids and 5-40 nm large size inorganic Fe oxy(hydr)oxides colloids (e.g., Stolpe and Hassellöv, 2007, 2010; Stolpe et al., 2010).

Complexation of trace metals with organic ligands of natural waters can be assessed using the available computer programs We used the geochemical program Visual MINTEQ (Gustafsson, 1999), version 2.52 for Windows, a recent adaption of the original code written by Allison et al. (1991) (see Unsworth et al., 2006 for vMINTEQ application example) in conjunction with a database and the NICA-Donnan humic ion binding model (Milne et al., 2003; Benedetti et al., 1995). Note that significant proportions of the data used to create this database represent soil humic and fulvic acids, and all aquatic FA and HA originated from temperate rivers and lakes, which may be quite different from the boreal subarctic waters studied in this research. Speciation calculations were performed for divalent metals, such as $\mathrm{Ca}, \mathrm{Mg}, \mathrm{Mn}$, $\mathrm{Co}, \mathrm{Ni}, \mathrm{Cu}, \mathrm{Zn}, \mathrm{Sr}, \mathrm{Cd}, \mathrm{Ba}, \mathrm{Pb}, \mathrm{Fe}, \mathrm{Al}, \mathrm{Dy}$, and $\mathrm{Th}^{\mathrm{IV}}$, and $\mathrm{U}^{\mathrm{VI}} \mathrm{O}_{2}$ for the following three typical samples of the lake chronosequence: U-6, U-1 and U-13 corresponding to peat abrasion, active growing lake and lake drainage (khasyrey) stage, respectively. Similar to the results of a previous study on the European part of the boreal zone (Vasyukova et al., 2010), calculated proportion of divalent metals bound with organic ligands was comparable $( \pm 30 \%)$ with the proportion of colloidal ( $1 \mathrm{kDa}-0.45 \mu \mathrm{m})$ fraction. However, a significant proportion $(>80 \%)$ of elements was concentrated in largesize $(10 \mathrm{kDa}-0.45 \mu \mathrm{m})$ colloidal fraction, which was not accounted for by the vMINTEQ model, notably for insoluble trivalent and tetravalent elements. There are several possible reasons for this discrepancy. First, organic ligands that complex TEs are smaller than the minimal cut-off $(1 \mathrm{kDa})$ of dialysis as shown by Pédrot et al. (2008); hence, these ligands are not detectable by the size-separation procedure. Indeed, using the in-situ dialysis procedure, we showed that between 15 and $35 \%$ of conventional DOC is concentrated in the fraction $<1 \mathrm{kDa}$ (Fig. 6). Second, stability constants of soil-derived humic and fulvic acids present in the model database are not necessarily good proxies for the aquatic dissolved organic

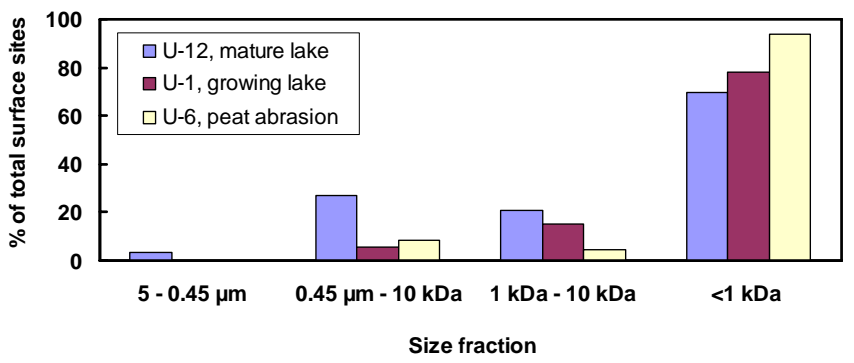

Fig. 17. Percentage of Fe colloids surface sites present in various size fractions for three typical stages of lake development. Total concentration of $>\mathrm{FeOH}^{\mathrm{O}}$ surface sites in samples is the following: $\mathrm{U}-6,23 \mu \mathrm{mol} \mathrm{L}^{-1}$; U-1, $0.5 \mu \mathrm{mol} \mathrm{L}^{-1}$; U-12, $0.07 \mu \mathrm{mol} \mathrm{L}^{-1}$.

matter subject to permafrost action. Finally, the speciation of TEs in colloids may be controlled by the interaction with $\mathrm{Fe}$ oxy(hydr)oxides rather than the DOC.

To evaluate the capacity of TEs to adsorb on the surface of organo-mineral colloids, we calculated the surface areas for the following fractions: $5-0.45 \mu \mathrm{m}, 0.45 \mu \mathrm{m}-10 \mathrm{kDa}$, $10 \mathrm{kDa}-1 \mathrm{kDa}$ and $<1 \mathrm{kDa}$ assuming that (i) the average diameters of colloids and particles are equal to 2.5, 0.1, 0.002 and $0.001 \mu \mathrm{m}$, respectively, (ii) the colloids have a spherical shape, (iii) the surface site density is $10 \mu \mathrm{mol} \mathrm{m}^{-2}$, and (iv) the iron hydroxide density is $4 \mathrm{~g} \mathrm{~cm}^{-3}$ (Fig. 17). Despite a significant amount of Fe present in the colloidal fraction, the main contribution to the total number of surface sites is provided by the smallest fraction $(<1 \mathrm{kDa})$. The fraction $0.45 \mu \mathrm{m}-10 \mathrm{kDa}$, concentrating more than $90 \%$ of the total dissolved $\mathrm{Fe}$ and insoluble trace metals contribute to less than $20-30 \%$ to the total number of surface sites and, hence, cannot accommodate all the insoluble trivalent and tetravalent metals present in the $<0.45 \mu \mathrm{m}$ filtered fraction on the surface.

Therefore, we should consider, in addition to complexation with DOM and adsorption of TEs on the surface, the incorporation of TEs inside the colloids. For a quantitative assessment of TE distribution between the liquid phase and the bulk of colloids adsorbed on the surface, we calculated the iron-normalized TE partition coefficient $\left(K_{\mathrm{d}}\right)$ between conventionally dissolved $(<1 \mathrm{kDa})$ and colloidal $(1 \mathrm{kDa}-0.45 \mu \mathrm{m})$ fractions assuming $\mathrm{Fe}$ is the main mineral component of the colloids defined as:

$K_{\mathrm{d}}=(\mathrm{TE} / \mathrm{Fe})_{\text {colloidal }} /(\mathrm{TE} / \mathrm{Fe})_{\text {dissolved }}$

The typical values ranged from 0.2 to 3.5 as illustrated for several insoluble elements in Fig. 18 for the three main stages of lake development, peat abrasion, active growth and mature (khasyrey) stage. These values are within the range reported in the earlier studies of boreal river waters (Pokrovsky et al., 2006; Vasyukova et al., 2010). There is a systematic decrease of $K_{\mathrm{d}}$ in the chronosequence of ecosystem development suggesting a progressive decrease in the role of mineral (Fe-rich) colloids in element binding in $<0.45 \mu \mathrm{m}$ fraction. Consistent 


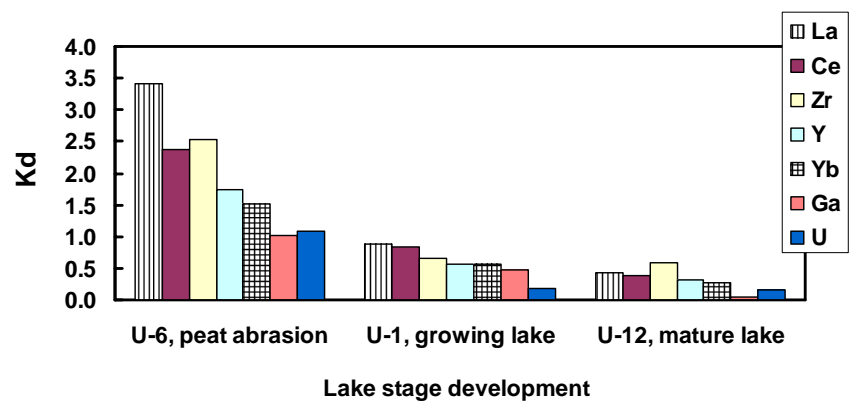

Fig. 18. Coefficients of trace element coprecipitation with colloidal $\mathrm{Fe}(\mathrm{III})$ oxy(hydr)oxides for three main stages of lake development, from the initial (peat abrasion) stage to the terminal (mature lake and khasyrey) stage.

with other observations presented above, it may be linked to the heterotrophic bacterial activity, which destabilizes colloids via selective consumption of organic substances, thus removing $\mathrm{Fe}$ from the system and decreasing the proportion of TEs linked to the mineral part of the colloids. A schematic cartoon demonstrating different types of colloidal aggregates and their evolution in the course of organic matter consumption is presented in the Supplement (ESM-5).

\section{Conclusions and applications of permafrost thawing}

In this study, we attempted to link the heterotrophic processes occurring in shallow, non-stratified thaw (thermokarst) lakes to the geochemistry of OC and major and trace elements. We observed a systematic decrease in the culturable heterotrophic bacteria, DOC, Fe, $\mathrm{Al}$ and TE concentrations along the chronosequence of ecosystem development, from permafrost subsidence to mature and drained lakes.

High concentration of DOC and normally insoluble elements ( $\mathrm{Fe}, \mathrm{Al}$, trivalent and tetravalent elements) is a typical feature of all studied thermokarst lakes. Most TEs are essentially present in colloidal large-size fraction $(0.45 \mu \mathrm{m}-$ $10 \mathrm{kDa})$, whereas some divalent metals $(\mathrm{Cu}, \mathrm{Cd})$ exhibit high affinity to small-size $(<1 \mathrm{kDa})$ colloidal fraction. We hypothesized that upon progressive consumption of OM by the different types of bacteria and photodegradation in the course of lake development, there is a systematic decrease in both DOC and dissolved metal concentrations.

In addition, bacterioplankton consumption of both truly dissolved $(<1 \mathrm{kDa})$ and colloidal $(1 \mathrm{kDa}-0.45 \mu \mathrm{m}) \mathrm{OM}$ may destabilize organo-mineral colloids leading to a significant reorganization of colloidal and particulate size fraction distribution. There is an increase in small size organic ligands binding divalent metals produced by the phytoplankton at the mature stage of ecosystem development at the expense of bacterioplankton mineralization of large colloidal size allochthonous humic and fulvic complexes. Alongside the sequence of lake evolution, we observed a steady decrease in the relative proportion of the "truly dissolved" ( $<1 \mathrm{kDa})$ fraction over sub-colloidal, particulate fraction $(5 \mu \mathrm{m}-0.45 \mu \mathrm{m})$, for most insoluble trivalent and tetravalent elements.

The systematic evolution of concentration and size fractionation of organic carbon and related trace elements in the course of thermokarst lake development may have important consequences on the speciation and bioavailability of the TEs in the water column, their flux to the rivers and the oceans during the high flooding period as well as the metals and carbon preservation in the sediments. In particular, we may notice an increase in potential bioavailability of metals in lake water during the evolution: the LMW complexes $(<1 \mathrm{kDa})$ or conventionally dissolved species are potentially bioavailable as the pore sizes of the cell walls transport channels (10$30 \AA$ in bacteria, 35-50 $\AA$ in plant cells (Carpita et al., 1979; Trias et al., 1992; Colombini et al., 1980) and are comparable to that of the $1 \mathrm{kDa}$ dialysis membrane $(1-3 \mathrm{~nm})$. This may not be true for organic carbon whose bioavailability decreases as its size decreases (Amon and Benner, 1996a, b), with the LMW fraction in Arctic rivers being more refractory than the colloidal $(1 \mathrm{kDa}-0.45 \mu \mathrm{m})$ fraction (Guo and MacDonald, 2006).

The observed trend of DOC concentration decreasing with the increase in lake age and size signifies that at the beginning of massive permafrost thawing, the DOC level in the lakes and draining rivers will increase following the appearance of new palsa subsidence, small ponds and peat abrasion, whereas in the course of system stabilization, the DOC level in the rivers draining the mature thermokarst lakes will decrease.

On a global scale, the increase of DOC concentration in surface waters due to global warming observed in the Nordic countries, British Isles, and northern and eastern United States (by approx. 10\% over $10 \mathrm{yr}$, Evans et al., 2005), is likely to be compensated by the decrease in DOC concentration in the course of existing thermokarst lake growth and drainage. The $\mathrm{CO}_{2}$ flux from the lake surface to the atmosphere associated with microbial degradation of organic matter is estimated to be $107 \pm 50 \mathrm{tC} \mathrm{km}^{-2} \mathrm{yr}^{-1}$ (Shirokova et al., 2009), which is approximately one order of magnitude higher than the organic carbon flux in the rivers of the northern part of western Siberia $\left(4-6 \mathrm{t} \mathrm{km}^{-2} \mathrm{yr}^{-1}\right.$, Maltseva et al., 1987). The $\mathrm{CO}_{2}$ flux is within the range reported for other boreal and temperate lakes in permafrostfree environments $\left(175 \mathrm{t} \mathrm{km}^{-2} \mathrm{yr}^{-1}\right.$, Casper et al., 2000; $28 \mathrm{t} \mathrm{km}^{-2} \mathrm{yr}^{-1}$, Teodoru et al., 2009) but significantly lower than that observed in the boreal ponds on peatlands (300$1000 \mathrm{t} \mathrm{C} \mathrm{km}^{-2} \mathrm{yr}^{-1}$, Hamilton et al., 1994) or boreal streams (1140 $\mathrm{t} \mathrm{km}^{-2} \mathrm{yr}^{-1}$, Teodoru et al., 2009).

Despite the average increase in thermokarst lake surface coverage by $4-6 \%$ during the last $36 \mathrm{yr}$ in the northern part of western Siberia documented within the zone of continuous permafrost (Kirpotin et al., 2008a, b), the decrease in DOC concentration during lake maturation (a factor of 2 to 5) will certainly overweigh the contribution of surface area 
increase. Therefore, the total stock of DOC and dissolved metals in thermokarst lakes will progressively decrease. This decrease will be accompanied by a relative increase in aquagenic OM (water column derived biopolymers and polysaccharides) versus pedogenic fulvic acids, probably with the same trend as that observed for temperate lakes (from April to July, Wilkinson et al., 1997).

The typical warming scenario in the Yukon River and other Artic river basins suggests an increase in the export flux of terrestrial OC into the ocean because old OC stored in Arctic peatlands and permafrost will be transported in a particulate phase (Guo and MacDonald, 2006) of low bioavailability (Benner et al., 2004). Small rivers may deliver their particulate OM load to newly-formed thermokarst lakes where it will be buried in the sediments instead of entering the hydrological network. In contrast to the rivers, in thermokarst lakes, the proportion of the particulate phase is likely to be small, and most OC present in the colloidal state is subject to significant bacterial and photodegradation, which is likely to intensify under warmer conditions. Therefore, organic carbon present in the thermokarst lake may be much more reactive and susceptible for exchange with the atmosphere as compared to the $\mathrm{OC}$ of rivers and soils, further increasing the positive feedback of permafrost systems' response to the warming of the climate.

Overall, the thermokarst lakes of western Siberia represent an important site for the degradation and deposition of released terrestrial permafrost $\mathrm{OC}$, thus corroborating the conclusion achieved in a recent study of the Kolyma paleoriver transect that the positive feedback of global warming from the degradation of permafrost carbon may be geographically displaced (Vonk et al., 2010). Further studies on lake biogeochemistry in the region of discontinuous and permafrost-free environments of western Siberia are needed to predict the net response of the boreal zone to the on-going environmental changes.

\section{Supplementary material related to this article is available online at: http://www.biogeosciences.net/8/565/2011/ bg-8-565-2011-supplement.pdf.}

\footnotetext{
Acknowledgements. We are grateful to J. Ingri, B. Stolpe and an anonymous reviewer for their insightful comments that allowed significant improvement of the manuscript. We thank A. Skugarev and V. Stepanova for their help with map drawing and field sampling, respectively. This work was supported by the French National Program INSU (EC2CO, Cytrix), GDRI CAR-WET-SIB and RFBR 08-05-92496.
}

Edited by: Ö. Gustafsson

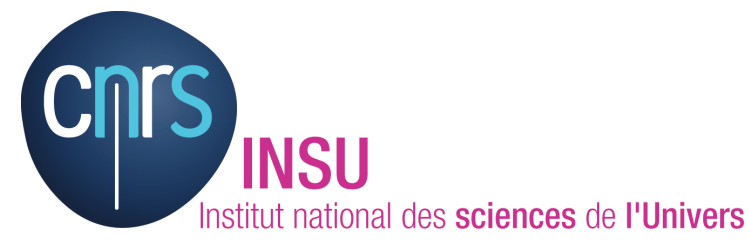

The publication of this article is financed by CNRS-INSU.

\section{References}

Allison, J. D., Brown, D. S., and Novo-Gradac, K. J.: MINTEQA2/PRODEFA2, A geochemical assessment model for environmental systems: version 3.0 user's manual, EPA/600/391/021, 1991.

Amon, R. M. W. and Benner, R.: Bacterial utilization of different size classes of dissolved organic matter, Limnol. Oceanogr., 41, 41-51, 1996a.

Amon, R. M. W. and Benner, R.: Photochemical and microbial consumption of dissolved organic carbon and dissolved oxygen in the Amazon River System, Geochim. Cosmochim. Ac., 60, 1783-1792, 1996b.

Andersson, K., Dahlqvist, R., Turner, D., Stolpe, B., Larsson, T., Ingri, J., and Andersson, P.: Colloidal rare earth elements in a boreal river: Changing sources and distributions during the spring flood, Geochim. Cosmochim. Ac., 70, 3261-3274, 2006.

Antoniades, D., Douglas, M. S. V., and Smol, J. P.: The physical and chemical limnology of 24 ponds and one lake from Isachsen, Ellef Ringnes Island, Int. Rev. Hydrobiol., 88, 519-538, 2003.

Arkhipov, S. A, Isayeva, L. L., Bespaly, V. G., and Glushkova, O.: Glaciation of Siberia and north-east USSR, Quaternary Sci. Rev., 5, 463-474, 1986.

Benedetti, M., Milne, C., Kinniburgh, D., van Riemsdijk, W., and Koopal, L.: Metal ion binding to humic substances: Application of the non ideal competitive adsorption model, Environ. Sci. Technol., 29, 446-457, 1995.

Benner, R., Benitez-Nelson, B., Kaiser, K., and Amon, R. M. W.: Export of young terrigenous dissolved organic carbon from rivers to the Arctic Ocean, Geophys. Res. Lett., 31, L05305, doi:10.1029/2003GL019251, 2004.

Blodau, C., Rees, R., Flessa, H., Rodionov, A., Guggenberger, G., Knorr, K.-H., Shibistova, O., Zrazhevskaya, G., Mikheeva, N., and Kasansky, O. A.: A snapshot of $\mathrm{CO}_{2}$ and $\mathrm{CH}_{4}$ evolution in a thermokarst pond near Igarka, northern Siberia, J. Geophys. Res.-Biogeo., 113, G03023, doi:10.1029/2007JG000652, 2008.

Breton, J., Vallières, C., and Laurion, I.: Limnological properties of permafrost thaw ponds in northeastern Canada, Can. J. Fish. Aquat. Sci., 66, 1635-1648, 2009.

Carpita, N., Sabularse, D., Montezinos, D., and Delmer, D.: Determination of the pore size of cell walls of living plant cells, Science, 205, 1144-1147, 1979.

Casper, P., Maberly, S. C., Grahame, H., Hall, G. H., and Finlay, B. J.: Fluxes of methane and carbon dioxide from a small productive lake to the atmosphere, Biogeochemistry, 49, 1-19, 2000.

Chen, Y.-W. and Buffle, J.: Conditions for the physico-chemical and microbial preservation of colloid characteristics of water samples. II. Physicochemical and microbial evolution, Water Res., 30, 2185-2192, 1996. 
Chin, W.-C., Orellana, M. V., and Verdugo, P.: Spontaneous assembly of marine dissolved organic matter into polymer gels, Nature, 391, 568-572, 1998.

Cole, J. J., Caraco, N. F., Kling, G. W., and Kratz, T. K.: Carbon dioxide supersaturation in the surface waters of lakes, Science, 265, 1568-1570, 1994.

Cole, J. J., Prairie, Y. T., Caraco, N. F., McDowell, W. H., Tranvik, L. J., Striegl, R. G., Duarte, C. M., Kortelainen, P., Downing, J. A., Middelburg, J. J., and Melack, J.: Plumbing the global carbon cycle: Integrating inland waters into the terrestrial carbon budget, Ecosystems, 10, 171-184, 2007.

Colombini, M.: Pore size and properties of channels from mitochondria isolated from Neurospora crassa, J. Membrane Biol., 53, 1432-1424, 1980.

Dahlqvist, R., Benedetti, M. F., Andersson, K., Turner, D., Larsson, T., Stolpe, B., and Ingri, J.: Association of calcium with colloidal particles and speciation of calcium in the Kalix and Amazon rivers, Geochim. Cosmochim. Ac., 68, 4059-4075, 2004.

De Haan, H.: Solar UV-light penetration and photodegradation of humic substances in peaty lake water, Limnol. Oceanogr., 38, 1072-1077, 1993.

Desyatkin, R. V.: Soil formation in thermokarst basin - alases of cryolithozone, Novosobirsk, Nauka, 43-52, 2008.

Desyatkin, A. R., Takakai, F., Fedorov, P., Nikolaeva, M. C., Desyatkin, R. V., and Hatano, R.: $\mathrm{CH}_{4}$ emission from different stages of thermokarst formation in Central Yakutia, East Siberia, Soil Sci. Plant Nutr., 55, 558-570, doi:10.1111/j.17470765.2009.00389.x, 2009.

Dia, A., Gruau, G., Olivié-Lauquet, G., Riou, C., Molénat, J., and Curmi, P.: The distribution of rare earth elements in groundwaters: Assessing the role of source-rock composition, redox changes and colloidal particles, Geochim. Cosmochim. Ac., 64, 4131-4151, 2000.

Duff, K. E., Laing, T. E., Smol, J. P., and Lean, D. R. S.: Limnological characteristics of lakes located across arctic treeline in northern Russia, Hydrobiologia, 391, 205-222, 1999.

Dupré, B., Viers, J., Dandurand, J.-L., Polvé, M., Benezeth, P., Vervier, Ph., and Braun, J.-J.: Major and trace elements associated with colloids in organic-rich river waters: ultrafiltration of natural and spiked solutions, Chem. Geol., 160, 63-80, 1999.

Dutta, K., Schuur, E. A. G., Neff, J. C., and Zimov, S. A.: Potential carbon release from permafrost soils of Northeastern Siberia, Glob. Change Biol., 12, 2336-2351, 2006.

Evans, C., Monteith, D., and Cooper, D.: Long-term increases in surface water dissolved organic carbon: observations, possible causes and environmental impacts, Environ. Pollut., 137, 55-71, 2005.

Eyrolle, F., Benedetti, M. F., Benaim, J. Y., and Février, D.: The distributions of colloidal and dissolved organic carbon, major elements, and trace elements in small tropical catchment, Geochim. Cosmochim. Ac., 60, 3643-3656, 1996.

Frey, K. E. and McClelland, J. W.: Impacts of permafrost degradation on arctic river biogeochemistry, Hydrol. Process., 23, 169$182,2009$.

Frey, K. E. and Smith, L. C.: Amplified carbon release from vast West Siberian peatlands by 2100 , Geophys. Res. Lett., 32, L09401, doi:10.1029/2004GL022025, 2005.

Frey, K. E., Siegel, D. I., and Smith, L. C.: Geochemistry of west Siberian streams and their potential response to permafrost degradation, Water Resour. Res., 43, W03406, doi:10.1029/2006WR004902, 2007.

Gaillardet, J., Viers, J., and Dupré, B.: Treatise on Geochemistry, in: Surface and Ground Water, Weathering, and Soils, edited by: Holland, H. D. and Turekian, K. K., Elsevier-Pergamon, Oxford, 5, 225-272, 2003.

Gordeev, V. V., Rachold, V., and Vlasova, I. E.: Geochemical behaviour of major and trace elements in suspended particulate material of the Irtysh river, the main tributary of the $\mathrm{Ob}$ river, Siberia. Appl. Geochem., 19, 593-610, 2004.

Gruber, N., Friedlingstein, P., Field, C. B., Valentini, R., Heimann, M., Richey, J. E., Romero-Lankao, P., Schulze, D., and Chen, C.-T. A.: The vulnerability of the carbon cycle in the 21 st century: An assessment of carbon-climate-human interactions, in: The Global Carbon Cycle: Integrating Humans, Climate, and the Natural World, edited by: Field, C. B. and Raupach, M. R., Island Press, Washington (DC), 45-76, 2004.

Guo, L. and MacDonald, R. W.: Source and transport of terrigenous organic matter in the upper Yukon River: Evidence from isotope $\left(\delta^{13} \mathrm{C}, \Delta^{14} \mathrm{C}\right.$, and $\left.\delta^{15} \mathrm{~N}\right)$ composition of dissolved, colloidal, and particulate phases, Global Biogeochem. Cy., 20, GB2011, doi:10.1029/2005GB002593, 2006.

Gustafsson, J.: http://www2.lwr.kth.se/English/OurSoftware/ vminteq/, A Windows version of MINTEQA2 website, 1999.

Hamilton, J. D., Kelly, C. A., Rudd, J. W. M., Hesslein, R. H., and Roulet, N. T.: Flux to the atmosphere of $\mathrm{CH}_{4}$ and $\mathrm{CO}_{2}$ from wetland ponds on the Hudson Bay lowlands (HBLs), J. Geophys. Res., 99(D1), 1495-1510, 1994.

Hamilton-Taylor, J., Smith, E. J., Davison, W., and Sugiyama, M.: Resolving and modeling the effects of Fe and Mn redox cycling on trace metal behavior in a seasonally anoxic lake, Geochim. Cosmochim. Ac., 69, 1947-1960, 2005.

Helms, J. R., Stubbins, A., Ritchie, J. D., Minor, E. C., Kieber, D. J., and Mopper, K.: Absorption spectral slopes and slope ratios as indicators of molecular weight, source, and photobleaching of chromophoric dissolved organic matter, Limnol. Oceanogr., 53, 955-969, 2008.

Hinkel, K. M., Eisner, W. R., Bockheim, J. G., Nelson, F. E., Peterson, K. M., and Dai, X.: Spatial Extent, Age, and Carbon Stoks in Drained Thaw Lake Basins on the Barrow Peninsula, Alaska, Arct. Antarct. Alp. Res., 35, 291-300, 2003.

Hoffmann, S. R., Shafer, M. M., and Armstrong, D. E.: Strong colloidal and dissolved organic ligands binding copper and zinc in rivers, Environ. Sci. Technol., 41, 6996-7002, 2007.

Hope, D., Kratz, T. K., and Riera, J. L.: The relationship between $\mathrm{pCO}_{2}$ and dissolved organic carbon in the surface waters of 27 northern Wisconsin lakes, J. Environ. Qual., 49, 1442-1445, 1996.

Ingri, J., Widerlund, A., Land, M., Gustafsson, O., Andersson, P. S., and Öhlander, B.: Temporal variations in the fractionation of the rare earth elements in a boreal river; the role of colloidal particles, Chem. Geol., 166, 23-45, 2000.

Ingri, J., Pekka, L., Dauvalter, V., Rodushkin, I., and Peinerud, E.: Manganese redox cycling in Lake Imandra: impact on nitrogen and the trace metal sediment record, Biogeosciences Discuss., 8 , 273-321, doi:10.5194/bgd-8-273-2011, 2011.

Johannesson, K. H. and Zhou, X.: Origin of middle rare earth element enrichments in acid waters of a Canadian High Arctic lake, Geochim. Cosmochim. Ac., 63, 153-165, 1999. 
Johannesson, K. H., Tang, J., Daniels, J. M., Bounds, W. J., David, J., and Burdige, D. J.: Rare earth element concentrations and speciation in organic-rich blackwaters of the Great Dismal Swamp, Virginia, USA, Chem. Geol., 209, 271-294, 2004.

Jonsson, A., Meili, M., Bergstrom, A.-K., and Jansson, M.: Wholelake mineralization of allochthonous organic carbon in a large humic lake (Ortrasket, N. Sweden), Limnol. Oceanogr., 46, 1691-1700, 2001.

Jonsson, A., Aberg, J., Lindroth, A., and Jansson, M.: Gas transfer rate and $\mathrm{CO}_{2}$ flux between an unproductive lake and the atmosphere in northern Sweden, J. Geophys. Res., 113, G04006, doi:10.1029/2008JG000688, 2008.

Kelly, C. A., Fee, E., Ramlal, P. S., Rudd, J. W. M., Hesslein, R. H., Anema, C., and Schindler, E. U.: Natural variability of carbon dioxide and net epilimnetic production in the surface waters of boreal lakes of different sizes, Limnol. Oceanogr., 46, 10541064, 2001.

Kerner, M., Hohen, H., Ertl, S., Reckermann, M., and Stitzy, A.: Self-organization of dissolved organic matter to micelle-like microparticles in river water, Nature, 422, 150-153, 2003.

Kirpotin, S. N., Naumov, A. V., Vorobiov, S. N., MironychevaTokareva, N. P., Kosych, N. P., Lapshina, E. D., Marquand, J., Kulizhski, S. P., and Bleuten, W.: Western-Siberian Peatlands: Indicators of Climate Change and Their Role in Global Carbon Balance. Chapter 33, in: Climate Change and Terrestrial Carbon Sequestration in Central Asia, edited by: Lal, R., Suleimenov, M., Stewart, B. A., Hansen, D. O., and Doraiswamy, P., Taylor and Francis, Amsterdam, Holland, 453-472, 2007.

Kirpotin, S. N., Polishchuk, Yu. M., and Bryksina, N. A.: Dynamics of thermokarst lakes areas in continuous and discontinuous cryolithozones of Western Siberia under global warming, Vestnik of Tomsk State University, 311, 185-189, 2008a (in Russian).

Kirpotin, S., Polishchuk, Yu., Zakharova, E., Shirokova, L., Pokrovsky, O., Kolmakova, M., and Dupre, B.: One of possible mechanisms of thermokarst lakes drainage in West-Siberian North, Int. J. Environ. Stud., 65, 631-635, 2008b.

Kirpotin, S. N., Berezin, A., Bazanov, V., Polishchuk, Y., Vorobiev, S., Mozgolin, B., Aakerman, E., Mironycheva-Tokareva, N., Volkova, I., Dupré, B., Porkovsky, O. S., Koiraev, A., Zakharova, E., Shirokova, L., Viers, J., and Kolmakova, M.: West Siberian wetlands as indicator and regulator of climate change on the global scale, Int. J. Environ. Stud., 66(4), 409-421, doi:10.1080/00207230902753056, 2009.

Kling, G. W., Kipphut, G. W., and Miller, M. C.: Arctic lakes and streams as gas conduits to the atmopshere: implications for tundra carbon budgets, Science, 251, 298-301, 1991.

Kling, G. W., O'Brien, W. J., Miller, M. C., and Hershey, A. E.: The biogeochemistry and zoogeography of lakes and rivers in arctic Alaska, Hydrobiologia, 240, 1-14, 1992.

Kortelainen, P., Rantakari, M., Huttunen, J. T., Mattsson, T., Alm, J., Juutinen, S., Larmola, T., Silvola, J., and Martikainen, P. J.: Sediment respiration and lake trophic state are important predictors of large $\mathrm{CO}_{2}$ evasion from small boreal lakes, Glob. Change Biol., 12, 1554-1567, 2006.

Kritzberg, E. S., Cole, J. J., Pace, M. L., Granéli, W., and Bade, D. L.: Autochthonous versus allochthonous carbon sources of bacteria: results from whole-lake ${ }^{13} \mathrm{C}$ addition experiments, Limnol. Oceanogr., 49, 588-596, 2004.

Kumke, T., Ksenofontova, M., Pestryakova L., Nazarova, L., and
Hubberten, H.-W.: Limnological characteristics of lakes in the lowlands of Central Yakutia, Russia, J. Limnol., 66, 40-53, 1007.

Laurion, I., Vincent, W. F., MacIntyre, S., Retamal, L., Dupont, C., Francus, P., and Pienitz, R.: Variability in greenhouse gas emissions from permafrost thaw ponds, Limnol. Oceanogr., 55 , 115-133, 2010.

Lead, J. R., Wilkinson, K. J., Balnois, E., Cutak, B. J., Larive, C. K., and Beckett, R.: Diffusion coefficients and polydispersities of the Suwannee River Fulvic Acid: Comparison of Fluorescence correlation spectroscopy, pulsed-field gradient nuclear magnetic resonance, and flow field-flow fractionation, Environ. Sci. Technol., 34, 3508-3513, 2000.

Lim, D. S. S., Douglas, M. S. V., Smol, J. P., and Lean, D. R. S.: Physical and chemical limnological characteristics of 38 lakes and ponds on Bathurst Island, Nunavut, Canadian High Arctic, Int. Rev. Hydrobiol., 86, 1-22, 2001.

Lim, D. S. S., Douglas, M. S. V., and Smol, J. P.: Limnology of 46 lakes and ponds on Banks Island, N.W.T., Canadian Arctic Archipelago, Hydrobiologia, 545, 11-32, 2005.

Maltseva, A. V., Tarasov, M. N., and Smirnov, M. P.: Discharge of organic substances from the USSR territory, Gidrokhimicheskie Materialy, 102, 1-118, 1987 (in Russian).

Michelutti, N., Douglas, M. S. V., Lean, D. R. S., and Smol, J. P.: Physical and chemical limnology of 34 ultra-oligotrophic lakes and ponds near Wanniatt Bay, Victoria Island, Arctic Canada, Hydrobiologia, 482, 1-13, 2002a.

Michelutti, N., Douglas, M. S. V., Muir, D. C. G., Wang, X., and Smol, J. P.: Limnological characteristics of 38 lakes and ponds on Axel Heiberg Island, High Arctic Canada, Int. Rev. Hydrobiol., 87, 385-399, 2002b.

Milne, C. J., Kinniburgh, D. G., van Riemsdijk, W. H., and Tipping, E.: Generic NICA-Donnan model parameters for metal-ion binding by humic substances, Environ. Sci. Technol., 37, 958-971, 2003.

Pedrós-Alió, C.: Marine microbial diversity: can it be determined?, Trends Microbiol., 14, 257-263, 2006.

Pédrot, M., Dia, A., Davranche, M., Coz, M. B., Henin, O., and Gruau G.: Insights into colloid-mediated trace element release at the soil/water interface, J. Colloid Interf. Sci., 325, 187-197, 2008.

Perret, D., Gaillard J.-F., Dominik, J., and Atteia, O.: The diversity of natural hydrous iron oxides, Environ. Sci. Technol., 34, 35403546, 2000.

Pienitz, R., Smol, J. P., and Lean, D. R. S.: Physical and chemical limnology of 24 lakes located between Yelloknife and Contwoyto Lake, Northwest Territories (Canada), Can. J. Fish. Aquat Sci., 54, 347-358, 1997a.

Pienitz, R., Smol, J. P., and Lean, D. R. S.: Physical and chemical limnology of 59 lakes located between the southern Yukon and the Tuktoyaktuk Peninsula, Northwest Territories (Canada), Can. J. Fish. Aquat. Sci., 54, 330-346, 1997b.

Pienitz, R., Doran, P. T., and Lamoureux, S. F.: Origin and geomorphology of lakes in the polar regions, in: Polar lakes and rivers - limnology of arctic and antarctic aquatic ecosystems, edited by: Vincent, W. F. and Laybourn-Parry, J., Oxford Univ. Press, 25-41, 2008

Pokrovsky, O. and Schott, J.: Iron colloids/organic matter associated transport of major and trace elements in small boreal rivers and their estuaries (NW Russia), Chem. Geol., 190, 141-179, 
2002.

Pokrovsky, O. S., Schott, J., and Dupré, B.: Trace element fractionation and transport in boreal rivers and soil porewaters of permafrost-dominated basic terrain in Central Siberia, Geochim. Cosmochim. Ac., 70, 3239-3260, 2006.

Pokrovsky, O. S., Viers, J., Shirokova, L. S., Shevchenko, V. P., Filipov, A. S., and Dupré, B.: Dissolved, suspended, and colloidal fluxes of organic carbon, major and trace elements in Severnaya Dvina River and its tributary, Chem. Geol., 273, 136-149, 2010.

Pontér, C., Ingri, J., and Boström, K.: Geochemistry of manganese in the Kalix River, northern Sweden, Geochim. Cosmochim. Ac., 65, 1485-1494, 1992.

Prentki, R. T., Miller, M. C., Barsdate, R. J., Alexander, V., Kelley, J., and Coyne, P.: Chemistry, in: Limnology of Tundra Ponds, Barrow, Alaska, edited by: Hobbie, J. E., Stroudsburg, Pa.: Dowden, Hutchinson and Ross, US/IBP synthesis series, 13, 76-178, 1980.

Riordan, B., Verbyla, D., and McGuire, A. D.: Shrinking ponds in subarctic Alaska based on 1950-2002 remotely sensed images, J. Geophys. Res., 11, G04002, doi:10.1029/2005JG000150, 2006.

Rühland, K. and Smol, J. P.: Limnological characteristics of 70 lakes spanning Arctic treeline from Coronation Gulf to Great Slave lake in the Central Northwest territories, Canada, Int. Rev. Hydrobiol., 83, 183-203, 1998.

Semiletov, I. P., Pipko, I. I., Pivovarov, N. Ya., Popov, V., Zimov, S. A., Voropaev, Yu. V., and Daviodov, S. P.: Atmospheric carbon emission from North Asian Lakes: a factor of global significance, Atmos. Environ., 30, 1657-1671, 1996.

Schuur, E. A. G., Bockhein, J., Canadell, J. P., Euskirchen, E., Field, C. B., Goryachkin, S. V., Hagemann, S., Kuhry, P., Lafleur, P. M., Lee, H., Mazhitova, G., Nelson, F. E., Rinke, A., Romanovsky, V. E., Shiklomanov, N., Tarnocai, C., Venesy, S., Vogel, J. G., and Zimov, S. A.: Vulnerability of permafrost carbon to climate change: Implications for the global carbon cycle, BioScience, 58, 701-714, 2008.

Shirokova, L. S., Pokrovsky, O. S., Kirpotin, S. N., and Dupré, B.: Heterotrophic bacterio-plankton in thawed lakes of northern part of Western Siberia controls the $\mathrm{CO}_{2}$ flux to the atmosphere, Int. J. Environ. Stud., 66(4), 433-445, doi:10.1080/00207230902758071, 2009.

Shirokova, L. S., Pokrovsky, O. S., Viers, J., Klimov, S. I., Moreva, O. Yu., Zabelina, S. A., Vorobieva, T. Ya., and Dupré, B.: Diurnal variations of trace elements and heterotrophic bacterioplankton concentration in a small boreal lake of the White Sea basin, Ann. Limnol.-Int. J. Lim., 46, 67-75, doi:10.1051/limn/2010011, 2010.

Sholkovitz, E. R.: The aquatic chemistry of rare earth elements in rivers and estuaries, Aquat. Geochem., 1, 1-34, 1995.

Smith, L. C., Sheng, Y., McDonald, G. M., ad Hinzman, L. D.: Disappearing Arctic lakes, Science, 308, 1429, doi:10.1126/science.1108142, 2005.

Sobek, S., Algesten, G., Bergstrom, A.-K., Jansson, M., and Tranvik, L. J.: The cathcment and climate regulation of $\mathrm{pCO}_{2}$ in boreal lakes, Glob. Change Biol., 9, 630-641, 2003.

Solovieva, N., Jones, V. J., Nazarova, L., Brooks, S. J., Birks, H. J. B., Grytnes, J.-A., Appleby, P. G., Kauppila, T., Kondratenok, B., Renberg, I., and Ponomarev, V.: Palaeolimnological evidence for recent climatic change in lakes from the northern Urals, arctic Russia, J. Paleolimnol., 33, 463-482, 2005.
Summers, R. S., Cornel, P. K., and Roberts, P. V.: Molecular size distribution and spectroscopic characterization of humic substances, Sci. Total Environ., 62, 27-37, 1987.

Stolpe, B. and Hassellöv, M.: Changes in size distribution of fresh water nanoscale colloidal matter and associated elements on mixing with seawater: Geochim. Cosmochim. Ac., 71, 3292-3301, 2007.

Stolpe, B. and Hassellöv, M.: Nanofibrils and other colloidal biopolymers binding trace elements in coastal seawater: Significance for variations in element size distributions, Limnol. Oceanogr., 55(1), 187-202, 2010.

Stolpe, B., Guo L., Shiller, A. M., and Hassellöv, M.: Size and composition of colloidal organic matter and trace elements in the Mississippi River, Pearl River and the northern Gulf of Mexico, as characterized by flow field-flow fractionation, Mar. Chem., 118, 119-128, 2010.

Teodoru, C. R., del Giorgio, P. A., Prairie, Y. T., and Camire, M.: Patterns in $\mathrm{pCO}_{2}$ in boreal streams and rivers of northern Quebec, Canada, Global Biogeochem. Cy., 23, GB2012, doi:10.1029/2008GB003404, 2009.

Tranvik, L. J.: Availability of dissolved organic carbon for planktonic bacteria in oligotrophic lakes of differing humic content, Microbiol. Ecol., 16, 311-322, 1988.

Tranvik, L. J., Downing, J. A., Cotner, J. B., Loiselle, S. A., Striegl, R. G., Ballatore, T. J., Dillon, P., Finlay, K., Fortino, K., Knoll, L. B., Kortelainen, P. L., Kutser, T., Larsen, S., Laurion, I., Leech, D. M., McCallister, S. L., McKnight, D. M., Melack, J. M., Overholt, E., Porter, J. A., Prairie, Y., Renwick, W. H., Roland, F., Sherman, B. S., Schindler, D. W., Sobek, S., Tremblay, A., Vanni, M. J., Verschoor, A. M., von Wachenfeldt, E., and Weyhenmeyer, G. A.: Lakes and reservoirs as regulators of carbon cycling and climate, Limnol. Oceanogr., 54, 2298-2314, 2009.

Trias, J., Jarlier, V., and Benz, R.: Porins in the cell wall of mycobacteria, Science, 258(5087), 1479-1481, 1992.

Unsworth, E. R., Warnken, K. W., Zhang, H., Davison, W., Black, F., Buffle, J., Cao, J., Cleven, R., Galceran, J., Gunkel, P., Kalis, E., Kistler, D., van Leeuwen, H. P., Martin, M., Noël, S., Nur, Y., Odzak, N., Puy, J., van Riemsdijk, W., Sigg, L., Temminghoff, E., Tercier-Waeber, M.-L., Toepperwien, S., Town R. M., Weng L., and Xue, H.: Model predictions of metal speciation in freshwaters compared to measurements by in situ techniques, Environ. Sci. Technol. 40, 1942-1949, 2006.

Vasyukova, E. V., Pokrovsky, O. S., Viers, J., Oliva, P., Dupré, B., Martin, F., and Candaudaup, F.: Trace elements in organic- and iron-rich surficial fluids of the Boreal zone: Assessing colloidal forms via dialysis and ultrafiltration, Geochim. Cosmochim. Ac., 74, 449-468, 2010.

Vonk, J. E., Sánchez-García, L., Semiletov, I., Dudarev, O., Eglinton, T., Andersson, A., and Gustafsson, Ö.: Molecular and radiocarbon constraints on sources and degradation of terrestrial organic carbon along the Kolyma paleoriver transect, East Siberian Sea, Biogeosciences, 7, 3153-3166, doi:10.5194/bg-73153-2010, 2010.

Walter, K. M., Zimov, S. A., Chanton, J. P., Verbyla, D., and Chapin III, F. S.: Methane bubbling from Siberian thaw lakes as a positive feedback to climate warming, Nature, 443, 71-75, 2006.

Walter, K. M., Smith, L. C., and Chapin, F. S.: Methane bubbling from northern lakes: present and future contributions to the global methane budget, Phil. T. R. Soc. S.-A., 365, 1657-1676, 
doi:10.1098/rsta.2007.2036, 2007.

Weishaar, J. L., Aiken, G. R., Bergamaschi, B. A., Fram, M. S., Fugii, R., and Mopper, K.: Evaluation of specific ultraviolet absorbance as an indicator of the chemical composition and reactivity of dissolved organic carbon, Environ. Sci. Technol., 37, 4702-4708, 2003.

Wetterich, S., Herzschuh, U., Meyer, H., Pestryakova, L., Plessen, B., Lopez, C. M. L., and Schirrmeister, L.: Evaporation effects as reflected in freshwaters and ostracod calcite from modern environments in Central and Northeast Yakutia (East Siberia, Russia), Hydrobiologia, 614, 171-195, 2008.

Wilkinson, K. J., Joz-Roland, A., and Buffle, J.: Different roles of pedogenic fulvic acids and aquagenic biopolymers on colloid aggregation and stability in freshwaters, Limnol. Oceanogr., 42, 1714-1724, 1997.
$\mathrm{Wu}, \mathrm{F}$. and Tanoue, E.: Isolation and partial characterization of dissolved copper-complexing ligands in streamwaters, Environ. Sci. Technol., 35, 3646-3652, 2001.

Xue, H. B. and Sigg, L.: Free cupric ion concentration and $\mathrm{Cu}(\mathrm{II})$ speciation in a eutrophic lake, Limnol. Oceanogr., 38, 12001213, 1993.

Zakharova, E. A., Kouraev, A. V., Kolmakova, M. V., Mognard, N. M., Zemtsov, V. A., and Kirpotin, S. N.: The modern hydrological regime of the northern part of Western Siberia from in situ and satellite observations, Int. J. Environ. Stud., 66, 447-463, doi:10.1080/00207230902823578, 2009.

Zimov, S. A., Voropaev, Y. V., Semiletov, I. P., Davidov, S. P., Prosiannikov, S. F., Chapin III, F. S., Chapin, M. C., Trumbore, S., and Tyler, S.: North Siberian lakes: a methane source fueled by Pleistocene Carbon, Science, 277, 800-802, 1997. 